\title{
Membrane Association of Lipoprotein Lipase and a cAMP-Binding Ectoprotein in Rat Adipocytes
}

\author{
Günter Müller, "‡ Eva-Marlen Wetekam, ${ }^{\ddagger}$ Christian Jung, ${ }^{\ddagger}$ and Wolfhard Bandlow\$ \\ Hoechst Aktiengesellschaft Frankfurt am Main, SBU Metabolic Diseases H 825, D-65926 Frankfurt am Main, Germany, and \\ Institut für Genetik und Mikrobiologie der Universität München, Maria-Ward-Strasse 1a, D-80638 München, Germany
}

Received May 4, 1994; Revised Manuscript Received July 12, $1994^{\circ}$

\begin{abstract}
AMP-binding ectoprotein (Gcel) and lipoprotein lipase (LPL) are anchored to plasma membranes of rat adipocytes by glycosylphosphatidylinositol (GPI) moieties as demonstrated by cleavage by bacterial phosphatidylinositol-specific phospholipase C (PI-PLC), reactivity with anti-crossreacting determinant antibodies (anti-CRD), and metabolic labeling with radiolabeled palmitic acid and myoinositol. Quantitative release from the membrane of LPL and Gcel requires both lipolytic removal of their GPI anchors and the presence of either $2 \mathrm{M} \mathrm{NaCl}$ or $1 \mathrm{mM}$ inositol 1,2-cyclic monophosphate or inositol 1 -monophosphate. PI-PLC-cleaved and released LPL or Gcel reassociates with isolated plasma membranes of rat adipocytes and, less efficiently, with membranes of $3 \mathrm{~T} 3$ fibroblasts. The specificity of the reassociation is demonstrated (i) by its inhibition after pretreatment of the membranes with trypsin, (ii) by its competition with inositol 1,2-cyclic monophosphate and inositol 1-monophosphate in a concentration-dependent manner, and (iii) by the limited number of binding sites. Enzymic or chemical removal as well as masking with anti-CRD antibodies of the terminal inositol (cyclic) monophosphate moiety of hydrophilic Gcel and LPL significantly impairs the reassociation. These data suggest that in rat adipocytes GPI-proteins are not readily released from the cell surface upon lipolytic cleavage, but remain associated through a receptor which specifically recognizes the terminal inositol (cyclic) monophosphate epitope of the (G)PI-PLCcleaved GPI moiety. This interaction may have implications for the regulated membrane release of GPIproteins and for their possible internalization.
\end{abstract}

GPI-proteins, ${ }^{1}$ a subclass of ectoproteins in both lower and higher eucaryotes, are anchored to the outer leaflet of the plasma membrane by covalently attached GPI glycolipids which are characterized by a high degree of structural conservation from yeast to man. Their linear core structure is built from phosphatidylinositol bound via nonacetylated glucosamine to three mannose residues. The nonreducing end is linked to ethanolamine via a phosphodiester bridge. From this conserved core glycan various carbohydrate and/ or phosphoethanolamine residues may branch off [for a review see Ferguson and Williams (1988), Low (1989), and McConville and Ferguson (1993)]. During the biosynthesis of GPI-proteins, the amino group of ethanolamine of the complete preformed GPI structure is coupled in a pseudo transpeptidation reaction to the carboxy terminus of the mature fully translated polypeptide chain, thereby replacing a transmembrane domain present in the protein precursor [for a review see Doering et al. (1990) and Thomas et al. (1990)].

Despite the lack of a cytoplasmic domain some GPI-proteins seem to have important roles in transmembrane signaling

* Address correspondence to this author at Hoechst A.G. Frankfurt am Main, Pharmaceutical Research Divison, SBU Metabolic Diseases H 825, D-65926 Frankfurt am Main, Germany. Tel: 069-305-4271; Fax: 069-311-454

'Hoechst A. G. Frankfurt am Main.

Institut für Genetik und Mikrobiologie der Universität München.

- Abstract published in Advance ACS Abstracts, September 1, 1994.

1 Abbreviations: GPI, glycosylphosphatidylinositol; GPI-protein, proteins which have been synthesized with a GPI membrane anchor irrespective of whether this moiety is preserved or cleaved; (G)PI-PLC(D), (glycosyl)phosphatidylinositol-specific phospholipase C(D); BATC, $4^{\prime}$-aminobenzamidotaurocholic acid; CRD, crossreacting determinant of the soluble form of trypanosomal variant surface glycoprotein; LPL, lipoprotein lipase; Gcel, glycolipid-anchored cAMP-binding ectoprotein TLC, thin-layer chromatography; SDS-PAGE, sodium dodecyl sulfatepolyacrylamide gel electrophoresis; TX-114, Triton X-114.

0006-2960/94/0433-12149\$04.50/0 processes, as has been suggested recently by two lines of evidence: First, cross-linking with antibodies of the T-cell antigens, Thy-1, Ly-6, Qa-2, and human decay-accelerating factor, leads to $\mathrm{Ca}^{2+}$ influx, altered tyrosine phosphorylation patterns, and cell proliferation, all of which are strictly dependent on the membrane anchorage of these proteins by GPI moieties (Robinson et al., 1989; Shenoy-Scaria et al., 1992; Su et al., 1991). Second, cleavage of the GPI anchor of heparan sulfate proteoglycan by a PLC in response to serum factors and insulin in a rat hepatocyte cell line has been correlated with the effects on contact inhibition and growth (Ishihara et al., 1987). To study in greater detail the molecular mechanisms of signal transfer across plasma membranes involving GPI-proteins, we are using isolated rat adipocytes. These cells are characterized by an exquisitely high sensitivity to stimulation of both short-term regulatory and metabolic processes as well as long-term growth effects by certain hormones like insulin which might use GPI-proteins as components in their signal transduction cascades.

In a first series of experiments, we studied the mode of membrane association of LPL and CAMP-binding ectoprotein, Gce 1, which have been demonstrated previously to be anchored in plasma membranes of cultured 3T3 adipocytes and the yeast Saccharomyces cerevisiae, respectively, by covalently attached GPI moieties (Chan et al., 1988; Müller et al., 1992, 1993). Here we show that Gcel and LPL are covalently modified by GPI in isolated rat adipocytes, too. However, after cleavage of the GPI anchors with PI-PLC, both Gcel and LPL remain associated with the adipocyte surface via bipolar interactions between the residual GPI structure and a plasma membrane receptor protein. Possible functional implications for binding of lipolytically cleaved GPI-proteins to plasma membranes will be discussed. 


\section{MATERIALS AND METHODS}

Materials. $8-\mathrm{N}_{3}-\left[{ }^{32} \mathrm{P}\right] \mathrm{cAMP}(20 \mathrm{Ci} / \mathrm{mmol})$ was bought from ICN, Eschwege, FRG; $m y o-\left[\mathrm{U}-{ }^{14} \mathrm{C}\right]$ inositol $(245 \mathrm{mCi}$ / $\mathrm{mmol})$, myo-[U-14 $\mathrm{C}]$ inositol 1 -monophosphate $(55 \mathrm{mCi} /$ $\mathrm{mmol})$, phosphatidyl[U-14 $\mathrm{C}]$ inositol $(220 \mathrm{mCi} / \mathrm{mmol}),\left[\mathrm{U}-{ }^{14} \mathrm{C}\right]-$ palmitic acid $(650 \mathrm{mCi} / \mathrm{mmol})$, and scintillation cocktail ACSII were provided by Amersham-Buchler, Braunschweig, FRG; EN ${ }^{3}$ HANCE was purchased from New England Nuclear, Dreieich, FRG; type 1 crude collagenase (240 units / $\mathrm{mg}$ ) was bought from CooperBiochemical, Freehold, NJ; protein A-Sepharose was provided by LKB/Pharmacia, Freiburg, FRG; glucosamine hydrochloride, mannose, mannose 6-phosphate, inositol 1,2-cyclic monophosphate, and inositol 1-monophosphate were provided by Sigma, Deisenhofen, FRG; recombinant $N$-glycanase F and protease inhibitors were delivered from Boehringer Mannheim, FRG; partially purified PI-PLC (Bacillus thuringiensis) was bought from Biotrend, Köln, FRG; other materials were obtained as described in previous publications (Müller \& Bandlow, 1989, 1991, 1992, 1993); male Wistar rats were bred and delivered by Hoechst AG, Tierzucht Kastengrund, FRG; polyclonal anti-CRD antibodies raised against purified soluble VSG (sVSG) from MITat 1.2 in New Zealand White rabbits were kind gifts from Dr. P. Overath, Tübingen, FRG; polyclonal rabbit antiserum against purified human milk LPL was donated by Dr. C.-S. Wang, Oklahoma, OK.

Isolation of Rat Adipocytes. Adipocytes were isolated from epididymal fat pads of $140-$ to $160-\mathrm{g}$ male Wistar rats under sterile conditions as described previously (Rodbell, 1964) with the following modifications: The fat tissue $(0.5-1 \mathrm{~g})$ was minced in $50-\mathrm{mL}$ polyethylene vials containing $3 \mathrm{~mL}$ of $\mathrm{KRH}$ buffer (10 mM HEPES/KOH, pH 7.4, $125 \mathrm{mM} \mathrm{NaCl}, 5.5$ $\mathrm{mM} \mathrm{KCl}, 2 \mathrm{mM} \mathrm{CaCl}_{2}, 1.5 \mathrm{mM} \mathrm{MgSO}_{4}, 2.5 \mathrm{mM} \mathrm{NaH}_{2} \mathrm{PO}_{4}$, $2.5 \% \mathrm{BSA}$, and $2 \mathrm{mM} \mathrm{D}$-glucose) and incubated (10-20 min, $\left.37^{\circ} \mathrm{C}\right)$ with collagenase $(0.1 \mathrm{mg} / \mathrm{mL}$ routinely, or as indicated in the figure legends) under gentle stirring with a Tefloncoated bar. The suspension was passed through a $150-\mu \mathrm{m}$ nylon filter, washed twice with $30 \mathrm{~mL}$ of $\mathrm{KRH}$ buffer containing 5\% BSA by flotation, collected from the top of the medium after centrifugation $\left(1000 \mathrm{~g}, 30 \mathrm{~s}, 25^{\circ} \mathrm{C}\right)$, and then washed once with $30 \mathrm{~mL}$ of $\mathrm{KRH}$ buffer containing $1 \%$ BSA and finally twice with $20 \mathrm{~mL}$ of Dulbecco's minimal essential medium (DMEM), 0.1\% BSA, $0.5 \mathrm{mM}$ glucose, and $25 \mathrm{mM}$ HEPES/KOH ( $\mathrm{pH}$ 7.4). After the final wash, the packed adipocyte suspension was diluted in $2 \mathrm{~mL}$ of the same medium $/ \mathrm{g}$ of fat tissue $\left(2-2.5 \times 10^{5}\right.$ cells $\left./ \mathrm{mL}\right)$ for subsequent photoaffinity or metabolic labeling.

Metabolic Labeling of Adipocytes. Freshly isolated or primary cultured adipocytes $\left(5 \mathrm{~mL} ; 2 \times 10^{5}\right.$ cells $\left./ \mathrm{mL}\right)$ were washed twice by flotation with $50 \mathrm{~mL}$ of inositol- and glucosefree DMEM containing 5\% fetal calf serum, $0.5 \%$ BSA, 2 $\mathrm{mM}$ sodium pyruvate, and $25 \mathrm{mM}$ HEPES/KOH ( $\mathrm{pH} 7.4$ ) and then suspended in $10 \mathrm{~mL}$ of the same medium containing 50 units $/ \mathrm{mL}$ penicillin, $25 \mu \mathrm{g} / \mathrm{mL}$ streptomycin, and $20 \mu \mathrm{Ci}$ of myo-[U-14 C]inositol or $100 \mu \mathrm{Ci}$ of $\left[\mathrm{U}^{14} \mathrm{C}\right]$ palmitic acid. After incubation $\left(12 \mathrm{~h}, 37^{\circ} \mathrm{C}\right)$ in $50-\mathrm{mL}$ polystyrene tubes under gentle agitation, the adipocytes were separated from the medium by flotation two times with $40 \mathrm{~mL}$ of DMEM containing $2.5 \%$ BSA, $0.5 \mathrm{mM}$ glucose, $10 \mathrm{mM}$ unlabeled myo-inositol (for inositol labeling only), and $25 \mathrm{mM}$ HEPES/ $\mathrm{KOH}(\mathrm{pH} 7.4)$ and finally concentrated to $2 \times 10^{5}$ cells $/ \mathrm{mL}$ of DMEM containing $0.1 \%$ BSA, $0.5 \mathrm{mM}$ glucose, and 25 mM HEPES/KOH ( $\mathrm{pH} 7.4)$.
Photoaffinity Labeling of Adipocytes and Plasma Membranes with $8-N_{3}-\left[{ }^{32} P\right] c A M P$. Freshly isolated adipocytes, 20 -mL portions of cells $\left(2 \times 10^{5}\right.$ cells $\left./ \mathrm{mL}\right)$, were washed by flotation once with $20 \mathrm{~mL}$ of DMEM containing $0.1 \% \mathrm{BSA}$, 25 mM HEPES/KOH (pH 7.4), 1 mM EDTA, 1 mM DTT, and $0.1 \mathrm{mM}$ PMSF concentrated to $2 \times 10^{6}$ cells $/ \mathrm{mL}$ in the same buffer $(1.9 \mathrm{~mL})$ and then transferred to the wells of 12-well culture plates. Photoaffinity labeling was performed as described (Pomerantz et al., 1975; Müller et al., 1993) with the following modifications: To each well was added $100 \mu \mathrm{L}$ of $8-\mathrm{N}_{3}$ - $\left.{ }^{32} \mathrm{P}\right]$ cAMP $(100 \mu \mathrm{Ci} / \mathrm{mL} ; 5 \mu \mathrm{M}), 50 \mathrm{mM}$ $\mathrm{KCl}, 40 \mathrm{mM} \mathrm{MgCl}_{2}, 10 \mathrm{mM} \mathrm{MnCl}_{2}$, and $2 \mathrm{mM}$ 5'-AMP. The suspension was incubated $\left(30 \mathrm{~min}, 20^{\circ} \mathrm{C}\right)$ in the dark in the absence or presence of $0.25 \mathrm{mM}$ unlabeled cAMP (as a control) and then irradiated at $312 \mathrm{nM}$ with a UV handlamp $(8000$ $\mu \mathrm{W} / \mathrm{cm}^{2}$ ) at a distance of $2 \mathrm{~cm}$ for $2 \mathrm{~min}$. After addition of $20 \mu \mathrm{L}$ of $10 \mathrm{mM}$ cAMP, the suspension was transferred to $30-\mathrm{mL}$ polystyrene tubes, diluted with $18 \mathrm{~mL}$ of DMEM containing $0.1 \%$ BSA, $0.5 \mathrm{mM}$ glucose, and $25 \mathrm{mM}$ HEPES (pH 7.4), and washed by flotation two times with the same buffer. For photoaffinity labeling of plasma membranes, the plasma membrane pellet was suspended in $1 \mathrm{~mL}$ of $20 \mathrm{mM}$ Tris- $\mathrm{HCl}$ ( $\mathrm{pH} 7.4$ ), $0.25 \mathrm{M}$ sucrose, $50 \mathrm{mM} \mathrm{KCl}, 2 \mathrm{mM} \mathrm{MgCl}_{2}$, $0.5 \mathrm{mM} \mathrm{MnCl}_{2}, 0.1 \mathrm{mM}$ 5'-AMP, $1 \mathrm{mMDTT}, 0.5 \mathrm{mM}$ EDTA, and $0.1 \mathrm{mM}$ PMSF at $0.2 \mathrm{mg}$ of protein $/ \mathrm{mL}$, transferred to the wells of 12-well culture plates, and supplemented with 2 $\mu \mathrm{Ci}$ of $8-\mathrm{N}_{3}-\left[{ }^{32} \mathrm{P}\right] \mathrm{cAMP}(0.1 \mathrm{nmol})$. The suspension was incubated $\left(30 \mathrm{~min}, 4^{\circ} \mathrm{C}\right)$ in the dark in the absence or presence of $0.1 \mathrm{mM}$ unlabeled cAMP (as a control) and then irradiated as described above. The labeling was terminated by the addition of $10 \mu \mathrm{L}$ of $10 \mathrm{mM}$ unlabeled cAMP and 5-fold dilution with $20 \mathrm{mM}$ Tris- $\mathrm{HCl}$ ( $\mathrm{pH} 7.4$ ), $0.25 \mathrm{M}$ sucrose, 1 mM EDTA, and $100 \mu \mathrm{M}$ PMSF. The photolabeled plasma membranes were centrifuged through a sucrose cushion as described for salt-washed membranes.

Preparation of Plasma Membranes. Adipocytes from 10 $\mathrm{g}$ of tissue (approximately $5 \times 10^{6}$ cells) were washed twice by flotation with homogenization buffer $(20 \mathrm{mM}$ Tris- $\mathrm{HCl}$, pH 7.4, $1 \mathrm{mM}$ EDTA, 0.25 M sucrose) containing $200 \mu \mathrm{M}$ PMSF and $0.5 \mu \mathrm{g} / \mathrm{mL}$ leupeptin, pepstatin, and aprotinin each, resuspended in $50 \mathrm{~mL}$ of the same buffer, homogenized with 10 strokes in a motor-driven ( $500 \mathrm{rpm})$ Teflon-in-glass homogenizer, and centrifuged $\left(1500 \mathrm{~g}, 5 \mathrm{~min}, 15^{\circ} \mathrm{C}\right)$. The infranatant below the fat cake was removed from the pelleted cell debris with a syringe. The homogenate was centrifuged $\left(12000 \mathrm{~g}, 15 \mathrm{~min}, 4^{\circ} \mathrm{C}\right)$. Plasma membranes were prepared according to published procedures (McKeel \& Jarett, 1970; Karnieli et al., 1981; Müller \& Wied, 1993) with the following modifications: The pellet was suspended in $15 \mathrm{~mL}$ of homogenization buffer and recentrifuged $(1000 \mathrm{~g}, 10 \mathrm{~min})$. Aliquots $(7.5 \mathrm{~mL}$ ) of the supernatant were supplemented with $32 \mathrm{~mL}$ of Percoll medium containing $0.25 \mathrm{M}$ sucrose and 20 $\mathrm{mM}$ Tris- $\mathrm{HCl}(\mathrm{pH} 7.4)$ and centrifuged $(48000 \mathrm{~g}, 20 \mathrm{~min}, 4$ ${ }^{\circ} \mathrm{C}$ ). Plasma membranes were recovered from the upper third of the gradient (white band, $2 \mathrm{~mL}$ ), diluted with $18 \mathrm{~mL}$ of homogenization buffer containing $200 \mu \mathrm{M} \mathrm{PMSF}$, and centrifuged $\left(20000 \mathrm{~g}, 30 \mathrm{~min}, 4^{\circ} \mathrm{C}\right)$. The pellet was resuspended in $10 \mathrm{~mL}$ of the same buffer and layered onto a $20-\mathrm{mL}$ cushion of $20 \mathrm{mM}$ Tris- $\mathrm{HCl}$ ( $\mathrm{pH} 7.4$ ), 1 mM EDTA, and 1.12 $\mathrm{M}$ sucrose. After centrifugation $\left(10000 \mathrm{~g}, 70 \mathrm{~min}, 4^{\circ} \mathrm{C}\right.$ ), the plasma membranes were recovered at the interface (2 $\mathrm{mL}$ ), diluted with $18 \mathrm{~mL}$ of homogenization buffer containing $200 \mu \mathrm{M}$ PMSF, and collected by centrifugation $(48000 \mathrm{~g}, 15$ $\min , 4^{\circ} \mathrm{C}$ ). The pellet was washed once with the same buffer 
and then resuspended in the desired buffer for further processing.

Salt Wash and Centrifugation of Plasma Membranes through a Cushion of Sucrose. The plasma membrane pellet (see above) was suspended in $2 \mathrm{M} \mathrm{NaCl}, 20 \mathrm{mM}$ Tris- $\mathrm{HCl}$ (pH 7.4), $1 \mathrm{mM}$ EDTA, and $100 \mu \mathrm{M}$ PMSF at $0.25 \mathrm{mg}$ of protein $/ \mathrm{mL}$ and incubated $\left(60 \mathrm{~min}, 4{ }^{\circ} \mathrm{C}\right)$. After 3 -fold dilution with $20 \mathrm{mM}$ Tris- $\mathrm{HCl}$ (pH 7.4), 1 mM EDTA, and $100 \mu \mathrm{M}$ PMSF, $6 \mathrm{~mL}$ of the suspension was layered onto a $3-\mathrm{mL}$ cushion of $0.55 \mathrm{M}$ sucrose, $20 \mathrm{mM}$ Tris- $\mathrm{HCl}$ ( $\mathrm{pH} 7.4$ ), $1 \mathrm{mM}$ EDTA, and $100 \mu \mathrm{M}$ PMSF and centrifuged $(150000 \mathrm{~g}$, $60 \mathrm{~min}, 4^{\circ} \mathrm{C}$, swing-out rotor). The supernatant above the sucrose layer was removed with a syringe and precipitated with $8 \%$ PEG 6000 in the presence of $100 \mu \mathrm{g} / \mathrm{mL}$ BSA (see below) prior to purification of Gcel and LPL. The membrane pellet was rinsed once with $10 \mathrm{~mL}$ of homogenization buffer and then used for solubilization of membranes and purification of the GPI-proteins.

Solubilization of Plasma Membranes. The plasma membrane pellet was suspended in 0.15\% BATC (Müller et al., 1994), $20 \mathrm{mM}$ Tris- $\mathrm{HCl}$ (pH 7.4), $1 \mathrm{mM}$ EDTA, $100 \mu \mathrm{M}$ PMSF, $50 \mu \mathrm{g} / \mathrm{mL}$ antipain hydrochloride, $0.5 \mu \mathrm{g} / \mathrm{mL}$ leupeptin, and pepstatin and aprotinin each at $0.1 \mathrm{mg}$ of protein/ $\mathrm{mL}$ and incubated $\left(30 \mathrm{~min}, 4^{\circ} \mathrm{C}\right)$. Samples $(2.5 \mathrm{~mL})$ were layered on top of a $1-\mathrm{mL}$ cushion of $0.55 \mathrm{M}$ sucrose, $20 \mathrm{mM}$ Tris- $\mathrm{HCl}(\mathrm{pH} 7.4), 1 \mathrm{mM}$ EDTA, and $100 \mu \mathrm{M}$ PMSF and centrifuged $\left(150000 \mathrm{~g}, 60 \mathrm{~min}, 4^{\circ} \mathrm{C}\right.$, swing-out rotor). The supernatant above the sucrose layer was removed with a syringe and used for purification of Gcel and LPL.

$N$-Glycanase Digestion of Plasma Membranes. Photolabeled plasma membranes were suspended in $0.1 \mathrm{M}$ sodium phosphate buffer ( $\mathrm{pH} \mathrm{8.6)}, 5 \mathrm{mM}$ DTT, $1 \%$ SDS, and 0.1 $\mathrm{mM}$ PMSF at $2 \mathrm{mg}$ of protein $/ \mathrm{mL}$. After heating $(5 \mathrm{~min}$, $\left.95^{\circ} \mathrm{C}\right)$ and centrifugation $(15000 \mathrm{~g}, 5 \mathrm{~min})$, the supernatant was diluted 10 -fold with the same buffer lacking SDS and a $0.5-\mathrm{mL}$ portion incubated $\left(16 \mathrm{~h}, 30^{\circ} \mathrm{C}\right)$ with 1.5 units of $\mathrm{N}$-glycosidase $\mathrm{F}$. The digestion was terminated by TCA precipitation. The acetone-washed and dried protein pellet was dissolved in sample buffer and analyzed by SDS-PAGE.

PI-PLC Digestion. For treatment of adipocytes, photoaffinity or meta bolically labeled cells $\left(2 \times 10^{5}\right.$ cells $\left./ \mathrm{mL}\right)$ were concentrated 10 -fold by flotation in DMEM containing 0.5 $\mathrm{mM}$ glucose, $0.1 \% \mathrm{BSA}$, and $25 \mathrm{mM}$ HEPES $/ \mathrm{KOH}(\mathrm{pH}$ 7.2). Portions $(2.5-\mathrm{mL})$ were incubated $\left(30 \mathrm{~min}, 37^{\circ} \mathrm{C}\right)$ with 2 units of partially purified PI-PLC (B. thuringiensis). After digestion, the adipocytes were washed by flotation with the initial buffer and adjusted to $2 \times 10^{5}$ cells $/ \mathrm{mL}$. For treatment of plasma membranes, the collected plasma membranes (50$100 \mu \mathrm{g}$ of protein) were suspended in $500 \mu \mathrm{L}$ of $25 \mathrm{mM}$ HEPES/KOH (pH 7.2), 1 mM EDTA, 1 mM DTT, and 200 $\mu \mathrm{M}$ PMSF and then incubated $\left(2 \mathrm{~h}, 30^{\circ} \mathrm{C}\right)$ with 0.2 units of PI-PLC.

Purification of Gcel. Affinity chromatography was performed as described (Müller \& Bandlow, 1992; Müller et al., 1993) using the following modifications: $1.8 \mathrm{~mL}$ of solubilized plasma membranes or PEG-precipitated proteins from saltwashed membranes (approximately 140-180 $\mu \mathrm{g}$ of protein isolated from $10^{6}$ cells) was supplemented with $200 \mu \mathrm{L}$ of 1.5 $\mathrm{M} \mathrm{NaCl}$ and then mixed with $8 \mathrm{~mL}$ of $N^{6}$-(2-aminoethyl)cAMP-Sepharose $(10 \mathrm{mg} / \mathrm{mL}$ in $20 \mathrm{mM}$ Tris- $\mathrm{HCl}, \mathrm{pH} 7.4$, $1 \mathrm{mM}$ EDTA). After incubation ( $30 \mathrm{~min}, 4^{\circ} \mathrm{C}$, gentle stirring), the mixture was loaded on top of $20-\mathrm{mL}$ spin columns, which were washed twice with $10 \mathrm{~mL}$ of $20 \mathrm{mM}$ Tris- $\mathrm{HCl}$ (pH 7.4), $100 \mathrm{mM}$ sodium citrate, $150 \mathrm{mM} \mathrm{NaCl}, 2 \mathrm{mM}$ DTT, $1 \mathrm{mM} \mathrm{MgCl} 2,1 \%$ BSA, $10 \%$ glycerol, and $0.1 \mathrm{mM}$
PMSF using centrifugation $\left(1000 \mathrm{~g}, 30 \mathrm{~s}, 4^{\circ} \mathrm{C}\right)$ and then eluted with $10 \mathrm{~mL}$ of the same buffer containing $0.1 \mathrm{mM}$ cAMP. The initial $1.5 \mathrm{~mL}$ of the eluate was desalted by centrifugation through a 5-mL column of Sephadex G-25 and then precipitated with $8 \%$ PEG 6000 . The precipitate was washed once with $0.8 \%$ PEG 6000 and then dissolved in $20 \mathrm{mM}$ Tris- $\mathrm{HCl}$ $(\mathrm{pH} 7.4)$ and $1 \mathrm{mM}$ EDTA.

Immunoprecipitation. Immunoprecipitation with polyclonal anti-LPL antibodies was performed according to Müller et al. (1994) by suspending the collected plasma membrane or PEG-precipitated proteins from salt-washed membranes in sample buffer, subsequent heating $\left(5 \mathrm{~min}, 95^{\circ} \mathrm{C}\right)$, and centrifugation followed by addition of anti-LPL antiserum to the diluted supernatant ( $0.1 \%$ final SDS concentration). Immunoprecipitation with anti-CRD antiserum was performed either with SDS ( $2 \%$ )-denatured membranes $(0.1 \%$ final SDS concentration) according to Müller et al. (1993) or with BATC $(0.1 \%$ or $2 \%)$-solubilized membranes $(0.1 \%$ final BATC concentration). For washing of the immunoprecipitates immunoprecipitation buffer containing $2 \%$ NP- $40,0.1 \%$ NP40 , and no detergent was used in this order. For sequential immunoprecipitation with anti-LPL and anti-CRD antibodies the washed anti-LPL immunoprecipitates were suspended in sample buffer, heated $\left(5 \mathrm{~min}, 95^{\circ} \mathrm{C}\right)$, and centifuged $(12000 \mathrm{~g}$, $5 \mathrm{~min}$ ). The supernatant was diluted 20 -fold with immunoprecipitation buffer lacking detergent and then incubated with anti-CRD antibodies.

Nitrous Acid Deamination. Samples of metabolically labeled and purified LPL or Gcel were dried and resuspended in $0.1 \mathrm{~mL}$ of $50 \mathrm{mM}$ sodium acetate (pH 3.5$)$. To one half of the sample was added $0.1 \mathrm{~mL}$ of $0.33 \mathrm{M} \mathrm{NaNO}_{3}$; the other half was supplemented with $0.1 \mathrm{~mL}$ of $0.33 \mathrm{M} \mathrm{NaCl}$ (control) as described (Ferguson et al., 1988). The samples were then incubated $\left(6 \mathrm{~h}, 25^{\circ} \mathrm{C}\right)$, dried again, resuspended in $10 \mathrm{~mL}$ of $\mathrm{H}_{2} \mathrm{O}$, desalted on $\mathrm{YC} 05$ ultrafiltration membranes (Amicon Corp., Freehold, NJ), and finally lyophilized prior to SDSPAGE or TLC analysis.

Miscellaneous Procedures. Published procedures were used for TX-114 partitioning (Bordier, 1981; Müller \& Bandlow, 1993), digestion with partially purified GPI-PLD from rabbit serum (Müller et al., 1992), PI-PLC/GPI-PLD digestion and affinity purification of Gcelp from S. cerevisiae (Müller \& Bandlow, 1994), TLC analysis (Müller \& Bandlow, 1993) followed by a second development using 1-butanol/ethanol/ $\mathrm{NH}_{4} \mathrm{OH} / \mathrm{H}_{2} \mathrm{O}(2: 2: 1: 2 \mathrm{v} / \mathrm{v})$, protein determination (Popov et al., 1975), SDS-PAGE, and fluorography using EN ${ }^{3}$ HANCE (Müller \& Zimmermann, 1987).

\section{RESULTS}

Identification, Topology, and Mode of Anchorage to Adipocyte Plasma Membranes of Gcel and LPL. Since to our knowledge no GPI-proteins have been described and characterized so far in isolated rat adipocytes, the first series of experiments was designed for their identification. Possible candidates were the cAMP-binding ectoprotein, Gcel and LPL, both of which have been found to be anchored in plasma membranes of mouse 3T 3 adipocytes by covalently attached GPI (Chan et al., 1988; Müller et al., 1993).

To identify Gcel, intact rat adipocytes were isolated by very mild collagenase digestion $\left(0.1 \mathrm{mg} / \mathrm{mL}, 20 \mathrm{~min}, 37^{\circ} \mathrm{C}\right)$ and photoaffinity-labeled with membrane-impermeable $8-\mathrm{N}_{3}$ [ $\left.{ }^{32} \mathrm{P}\right]$ cAMP. A single protein $\left(M_{\mathrm{r}}=62000\right)$ was photolabeled with high efficiency (Figure 1). The specificity of the photoaffinity labeling was demonstrated by inclusion of a 1000 - 


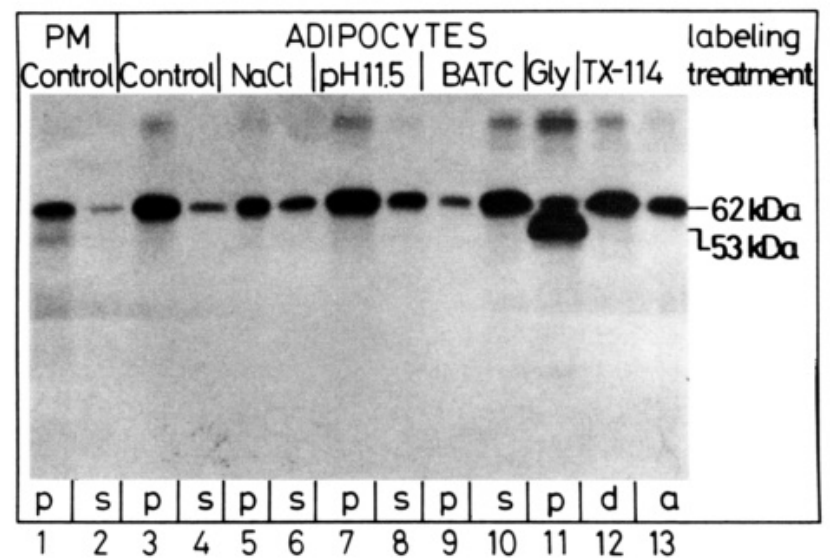

FIGURE 1: Photoaffinity labeling and membrane association of Gcel. Isolated adipocyte plasma membranes (PM; lanes 1 and 2 ) or adipocytes (lanes 3-13) were photoaffinity-labeled with $8-\mathrm{N}_{3}-\left[{ }^{32} \mathrm{P}\right]-$ cAMP (labeling). Plasma membranes were prepared from the adipocytes and aliquots ( $125 \mu \mathrm{g}$ of protein in $0.5-\mathrm{mL}$ final volume) incubated $\left(60 \mathrm{~min}, 30^{\circ} \mathrm{C}\right.$; treatment) in the absence (Control, lanes $1-4)$ or presence of $2 \mathrm{M} \mathrm{NaCl}$ (lanes 5 and 6), $0.5 \mathrm{M}\left(\mathrm{NH}_{4}\right)_{2} \mathrm{CO}_{3}$ at pH 11.5 (lanes 7 and 8 ), $0.15 \%$ BATC (lanes 9 and 10 ), $N$-glycanase (Gly, lane 11), or 2\% (final concn) TX-114 (lanes 12 and 13). After centrifugation through a sucrose cushion (lanes 1-11) or phase separation (lanes 12 and 13), the pellet (p) and supernatant (s) fractions or the detergent (d) and aqueous (a) phases, respectively, were analyzed by SDS-PAGE and autoradiography. Molecular masses indicated in the right margin were derived from marker proteins run in parallel.

fold molar excess of unlabeled cAMP (see Figure 2). Less than $2 \%$ of radiolabel was incorporated into the 62 -kDa protein compared to the absence of competitor (compare lanes 1 and 2). Most of the labeled protein was found associated with the pellet fraction of untreated plasma membranes after centrifugation through a sucrose cushion (Figure 1, lane 3), and only a minor portion was recovered from the soluble fraction (lane 4). To characterize the nature of the membrane association of Gce 1, photoaffinity-labeled plasma membranes were extracted with high salt or at alkaline $\mathrm{pH}$ followed by centrifugation. Densitometric scanning of the fluorogram of the SDS-PAGE analysis of the pellet and supernatant fractions revealed that high-salt and alkaline $\mathrm{pH}$ treatments caused membrane release of only $25-30 \%$ (lanes 5 and 6) and 10 $15 \%$ (lanes 7 and 8 ), respectively, of total photoaffinity-labeled Gcel. The limited extraction of Gcel under these conditions may be due to the basal (constitutive) activity of an endogenous GPI-PLC which has been identified in rat adipocytes (Müller et al., in press; see below and Discussion). The major portion of total Gcel remained associated with the membrane pellet (lanes 5 and 7) which was in agreement with the $70-80 \%$ recovered from the detergent-enriched phase after TX-114 partitioning (lanes 12 and 13). In contrast, more than $95 \%$ of the radiolabeled protein was solubilized by $0.15 \%$ BATC (lanes 9 and 10). According to this extraction and solubilization behavior Gcel is considered as membrane protein interacting with the membrane via either a proteinaceous transmembrane region or a covalently attached GPI moiety.

$\mathrm{N}$-Glycosylation of this protein was suggested by digestion of the photoaffinity-labeled plasma membranes with $\mathrm{N}$ glycanase under denaturing conditions. The fluorogram of the SDS-PAGE revealed a reduction in apparent molecular mass of the major portion of Gcel from 62 to $55-50 \mathrm{kDa}$ (lane 11). The glycoprotein nature of the photoaffinity-labeled protein and its labeling with the membrane-impermeable photoprobe using intact adipocytes provided strong evidence that at least the cAMP-binding domain of Gcel is located at the outer face of the plasma membrane. This view is in agreement with the high efficiency of photoaffinity labeling of sealed plasma membrane vesicles with $8-\mathrm{N}_{3}-\left[{ }^{32} \mathrm{P}\right]$ cAMP (lanes 1 and 2). The portion of right-side-out vesicles [about $65-75 \%$ as determined by trypsin digestion $(0.5 \mathrm{mg} / \mathrm{mL}$ for $60 \mathrm{~min}$ at $4^{\circ} \mathrm{C}$ ) of isolated plasma membrane vesicles and subsequent detection of the glucose transporter isoform Glut 4 by western blotting with antibodies against the carboxyterminal 16 amino acids which are located at the cytoplasmic face of the plasma membrane; thus the ratio of the anti-Glut4 immunoreactivity of intact trypsin-treated and solubilized undigested membranes will provide an estimate of the portion of right-side-out vesicles which have shielded the cytoplasmic face of the membrane (Glut4 epitope) against tryptic degradation (G. Müller, unpublished results)] correlated well with the 55-70\% efficiency of photoaffinity labeling of plasma membrane vesicles compared to identical amounts of total plasma membrane protein from photoaffinity-labeled adipocytes (compare 1 and 3). The shift in molecular mass after treatment with $\mathrm{N}$-glycanase demonstrates $\mathrm{N}$-glycosylation and, in addition, confirms the plasma membrane location of Gcel.

To substantiate these findings, the accessibility to proteolysis from the outer face of the plasma membrane was studied. For this, adipocytes were isolated with increasing concentrations of collagenase (Figure 2). The efficiency of the subsequent photoaffinity labeling of the extensively washed adipocytes with 8- $\mathrm{N}_{3}-[32 \mathrm{P}]$ cAMP declined dramatically with increasing collagenase concentrations (lanes 1,3 , and 4). The highest concentration $(1 \mathrm{mg} / \mathrm{mL})$ usually used for isolation of insulinsensitive rat adipocytes resulted in photoaffinity labeling of only $0.5 \%$ of the amount of Gcel detected after very mild collagenase treatment $(0.1 \mathrm{mg} / \mathrm{mL})$. Consequently, $0.1 \mathrm{mg}$ / $\mathrm{mL}$ was used for adipocyte isolation in all subsequent experiments. Interestingly, adipocytes isolated after incubation with $0.1-1 \mathrm{mg} / \mathrm{mL}$ collagenase did not differ significantly in their sensitivity and responsiveness of glucose transport stimulation by insulin (data not shown). Furthermore, no photoaffinity labeling of the regulatory subunit of protein kinase $A$ with $8-\mathrm{N}_{3}-\left[{ }^{32} \mathrm{P}\right] \mathrm{cAMP}$ using rat adipocytes isolated under these conditions was detectable after SDS-PAGE and fluorography of total cellular homogenate proteins (data not shown). This provides strong evidence for integrity of the major portion of these cells (including their insulin receptors). The pronounced sensitivity of Gcel to degradation by collagenase in intact cells confirms its ectoprotein nature. In contrast to the failure of photolabeling Gcel after harsh treatment with collagenase, incubation of plasma membranes prepared from photoaffinity-labeled adipocytes which have been isolated by mild collagenase treatment $(0.1 \mathrm{mg} / \mathrm{mL})$ with a second portion of collagenase $(0.66 \mathrm{mg} / \mathrm{mL}$; lane 5) revealed a broad area of photoaffinity-labeled proteins ranging from $62 \mathrm{kDa}$ (less than $3 \%$ of total radiolabel) to $51 \mathrm{kDa}$ ( $>40 \%$ of total radiolabel). This confirms that Gcel contains a cAMP-binding ectodomain which can be efficiently cleaved off by proteolytic activities contained in crude collagenase preparation. Obviously, the generated fragments fail to become photoaffinity-labeled.

To elucidate whether Gcel is modified by a covalently attached GPI moiety, metabolic labeling experiments were performed with typical constituents of GPI lipids. Adipocytes were labeled to equilibrium with $m y o-\left[{ }^{14} \mathrm{C}\right]$ inositol or $\left[{ }^{14} \mathrm{C}\right]-$ palmitic acid. Plasma membranes were prepared, and the solubilized Gcel protein was enriched by cAMP-Sepharose affinity chromatography. Eluted proteins were analyzed by SDS-PAGE and fluorography. Figure 2 shows that a single 


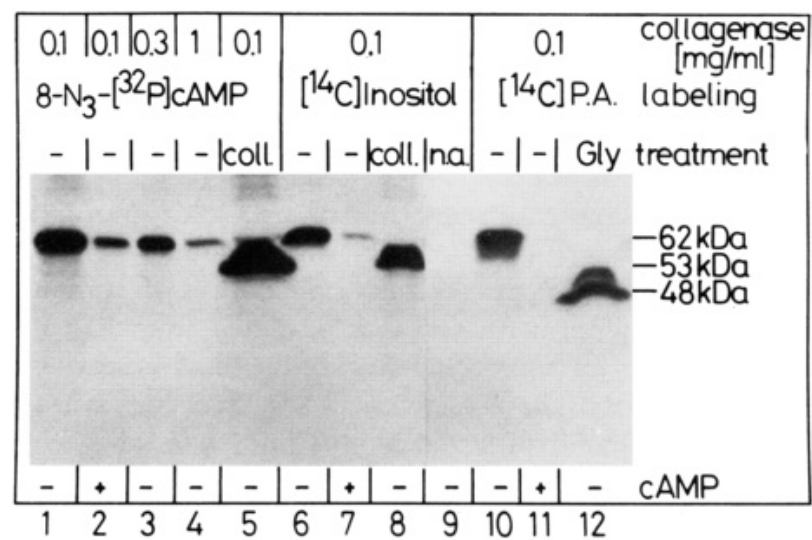

FIGURE 2: Metabolic labeling of Gcel. Adipocytes were prepared by digestion with $0.1,0.3$, or $1 \mathrm{mg} / \mathrm{mL}$ collagenase and then photoaffinity-labeled with $8-\mathrm{N}_{3}-\left[{ }^{32} \mathrm{P}\right] \mathrm{cAMP}$ (lanes 1-5) or metabolically labeled with myo- $\left[{ }^{14} \mathrm{C}\right]$ inositol (lanes $6-9$ ) or $\left[{ }^{14} \mathrm{C}\right]$ palmitic acid (P.A.; lanes 10-12) (labeling). The metabolically labeled Gce 1 was affinity-purified by cAMP-Sepharose chromatography from the solubilized plasma membranes (lanes 6-12). As controls, excess of cAMP was included during photoaffinity labeling (lane 2) or during affinity purification (lanes 7 and 11). Aliquots of total photoaffinitylabeled plasma membrane protein ( $75 \mu \mathrm{g}$ of protein) and of affinitypurified Gcel $(3500 \mathrm{dpm})$ were incubated $\left(30 \mathrm{~min}, 37^{\circ} \mathrm{C}\right)$ in $300-\mu \mathrm{L}$ final volume with $0.2 \mathrm{mg}$ (lane 5) or $0.02 \mathrm{mg}$ (lane 8) collagenase (coll.), respectively, or $\mathrm{N}$-glycanase (Gly) or subjected to nitrous acid deamination (n.a.) (treatment). Total photoaffinity-labeled plasma membrane proteins (lanes 1-5) and affinity-purified proteins (lanes 6-12) were analyzed by SDS-PAGE and fluorography. The molecular masses indicated in the right margin were derived from marker proteins run in parallel.

protein was recovered metabolically labeled with both myo$\left[{ }^{14} \mathrm{C}\right]$ inositol (lane 6) and $\left[{ }^{14} \mathrm{C}\right]$ palmitic acid (lane 10$)$. This protein comigrated with $62-\mathrm{kDa}$ photoaffinity-labeled Gcel (lane 1). The identity of the metabolically labeled and affinitypurified protein with photoaffinity-labeled Gcel was further substantiated by the sensitivity of the affinity-purified material to collagenase or $\mathrm{N}$-glycanase digestion. Subsequent SDSPAGE and fluorography shows the characteristic degradation patterns of the $\left[{ }^{14} \mathrm{C}\right]$ inositol-labeled protein by collagenase $(0.066 \mathrm{mg} / \mathrm{mL})($ lane 8$)$ and of the $\left[{ }^{14} \mathrm{C}\right]$ palmitic acid-labeled protein by $\mathrm{N}$-glycanase (lane 12 ) as observed for the photoaffinity-labeled protein (lane 5 and Figure 1, lane 11). The specificity of the affinity purification procedure was confirmed by addition of an excess of cAMP to a plasma membrane sample prior to incubation with the CAMP-Sepharose beads. Almost no $\left[{ }^{14} \mathrm{C}\right]$ inositol-labeled $\mathrm{Gcel}$ was recovered under these conditions (lanes 7 and 11). These data demonstrate that Gcel contains myo-inositol and palmitic acid. Incorporation of $m y o-\left[{ }^{14} \mathrm{C}\right]$ inositol into the GPI structure but not into the polypeptide portion of Gcel under the labeling conditions used was suggested by the complete loss of the ${ }^{14} \mathrm{C}$-label from the affinity-purified protein after nitrous acid deamination (lane 9), which causes removal of the phosphatidylinositol moiety from the GPI structure (Ferguson et al., 1988).

In order to examine whether LPL is also anchored by GPI in rat adipocytes, plasma membranes were prepared from myo- $\left[{ }^{14} \mathrm{C}\right]$ inositol-labeled cells and treated with high salt followed by centrifugation or subjected to TX-114 partitioning. LPL was assayed in the pellet/supernatant fractions or detergent/aqueous phases, respectively, by immunoprecipitation with specific anti-LPL antibodies. SDS-PAGE and fluorography of the immunoprecipitates (Figure 3, upper panel) revealed a single radiolabeled protein in the membrane pellet (lane 1) and detergent phase (not shown) with an apparent molecular mass of $60 \mathrm{kDa}$ identical to that



FIGURE 3: Digestion of LPL and Gcel with PI-PLC. Adipocytes were metabolically labeled with myo- $\left[{ }^{14} \mathrm{C}\right]$ inositol and subsequently incubated in the absence or presence of PI-PLC (B. thuringiensis). Plasma membranes were prepared and aliquots ( $75 \mu \mathrm{g}$ of protein in $300-\mu \mathrm{L}$ total volume) incubated $\left(30 \mathrm{~min}, 30^{\circ} \mathrm{C}\right)$ in the absence or presence of $2 \mathrm{M} \mathrm{NaCl}$ and centrifuged through a cushion of sucrose (lanes 1-6, 9-11) or subjected to TX-114 partitioning (lanes 7, 8, $12,13)$. The pellet (p) and supernatant (s) fractions or detergent (d) and aqueous (a) phases, respectively, were subjected to immunoprecipitation with anti-LPL antibodies or to affinity purification on cAMP-Sepharose. One half of the samples was analyzed directly by SDS-PAGE and fluorography (lanes 1-8) and the other half after immunoprecipitation with anti-CRD antibodies (lanes 9-13). Molecular masses of marker proteins are indicated in the right margin.

described for LPL in 3T3 adipocytes (Chan et al., 1988; Müller et al., 1993). Only marginal amounts were recovered from the supernatant fraction (lane 2) and aqueous phase (not shown), suggesting a tight association of amphiphilic LPL with the adipocyte plasma membrane.

The GPI Anchor of Gcel and LPL Is Cleaved by Bacterial $P I-P L C$. To demonstrate that Gcel and LPL are anchored to the adipocyte plasma membrane via covalently attached GPI moieties, we tested their accessibility to cleavage by bacterial PI-PLC. Adipocytes were metabolically labeled with myo- $\left[{ }^{14} \mathrm{C}\right]$ inositol and then incubated with PI-PLC (B. thuringiensis). Isolated plasma membranes were treated with high salt, subjected to centrifugation or TX-114 partitioning, and then assayed for the presence of LPL and Gcel. Figure 3 shows that incubation of intact adipocytes with PIPLC led to conversion of the major portion of ${ }^{14} \mathrm{C}$-labeled amphiphilic LPL (upper panel) and Gcel (lower panel) into their hydrophilic forms which now partitioned into the aqueous phases (compare lanes 7 and 8). However, release of the hydrophilic versions of LPL and Gcel from plasma membranes as assayed by centrifugation through a cushion of sucrose required the presence of high salt subsequent to the PI-PLC treatment (compare lanes 4 and 6). In the absence of salt the major fraction of LPL and Gcel remained associated with plasma membranes despite cleavage by PI-PLC (lanes 5). This pointed to the existence of bipolar interactions between the hydrophilic protein moieties of these GPI-proteins and the membrane surface.

Lipolytic cleavage of the GPI anchors of LPL and Gcel was confirmed by immunoprecipitation of $\left[{ }^{14} \mathrm{C}\right]$ inositol-labeled LPL and Gce 1 with anti-CRD antibodies from the supernatant (after centrifugation) or aqueous phase (after TX-114 partitioning). These antibodies exclusively recognize the PLCcleaved form of GPI-proteins, the major epitopes (CRD) residing in the inositol 1,2-cyclic monophosphate moiety formed during cleavage (Zamze et al., 1988). In addition, 


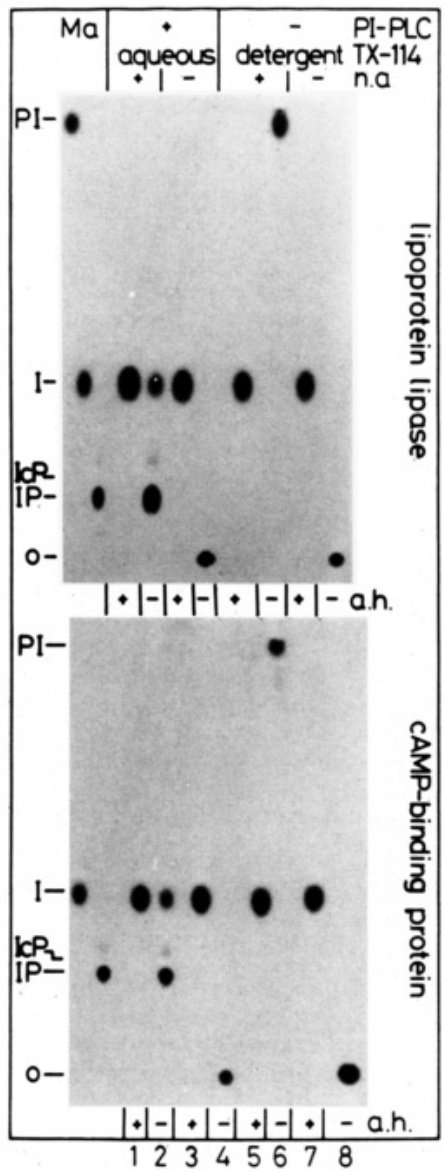

FIGURE 4: TLC Analysis of the GPI anchor of LPL and Gcel. Adipocytes were metabolically labeled with $m y o-\left[{ }^{14} \mathrm{C}\right]$ inositol and subsequently incubated in the absence or presence of PI-PLC (B. thuringiensis). LPL and Gcel were purified from solubilized plasma membranes by immunoprecipitation with anti-LPL antibodies or affinity purification on cAMP-Sepharose, respectively, and then subjected to TX-114 partitioning. Half of the aqueous and detergent phases was treated with nitrous acid (n.a.), and the other half was left untreated. Each sample was divided again and subjected to acid hydrolysis (a.h.) or left untreated and subsequently analyzed by TLC and fluorography. The positions of radiolabeled inositol 1-monophosphate (IP), myo-inositol (I), and phosphatidylinositol (PI) run in parallel as markers are indicated in the left margin (Ma). The position of inositol 1,2-cyclic monophosphate (IcP) was derived from the $R_{f}$ value as determined from a parallel TLC run with unlabeled compound which was identified by staining with $1 \mathrm{~N} \mathrm{H}_{2} \mathrm{SO}_{4}$. o, origin.

inositol monophosphate is recognized, albeit with lower efficiency. As can be seen from Figure 3, 80-90\% of total radiolabeled hydrophilic (lanes 12) or soluble (lanes 10) LPL and Gcel was immunoprecipitated by anti-CRD antibodies, whereas the amphiphilic (lanes 13) and membrane-associated versions (lanes 11) were not recognized. In agreement with the failure to release the two GPI-proteins from the adipocyte plasma membrane solely by cleavage of their GPI anchor (see above), inclusion of high salt prior to centrifugation was required for subsequent immunoprecipitation of LPL and Gce 1 with anti-CRD antibodies from the supernatant (compare lanes 9 and 10 ).

The ${ }^{14} \mathrm{C}$-radiolabel of the PI-PLC-cleaved LPL and Gcel from adipocytes metabolically labeled with $m y o-\left[{ }^{14} \mathrm{C}\right]$ inositol is in agreement with lipolytic processing of their amphiphilic versions by PI-PLC. To confirm the identity of $\left[{ }^{14} \mathrm{C}\right]$ inositol and to prove the cleavage specificity of the phospholipase used, we analyzed the acid hydrolysis and nitrous acid deamination products of the amphiphilic and hydrophilic forms of $\left[{ }^{14} \mathrm{C}\right]-$ inositol-labeled LPL and Gcel. Figure 4 shows that the major fraction of the radiolabel incorporated into LPL and Gcel from untreated adipocytes comigrated with inositol in TLC after acid hydrolysis of amphiphilic (lanes 7) or of amphiphilic deaminated material (lanes 5; compare with amphiphilic nonhydrolyzed material in lanes 8 ), but with phosphatidylinositol after nitrous acid deamination alone (lanes 6). Thus there was no significant conversion of $m y o-\left[{ }^{14} \mathrm{C}\right]$ inositol into other components in rat adipocytes during the period of metabolic labeling. Nitrous acid deamination of $\left[{ }^{14} \mathrm{C}\right]$ inositollabeled hydrophilic LPL and Gcel isolated from PI-PLCtreated adipocytes released $65-70 \%$ of the total radiolabel as inositol monophosphate and $20-30 \%$ as inositol (lanes 2; compare with nonhydrolyzed hydrophilic material in lanes 4). Acid hydrolysis of the deamination products identified $\left[{ }^{14} \mathrm{C}\right]$ inositol as the only radiolabel (lanes 1 ). The presence of inositol monophosphate after nitrous acid deamination of the PLC-cleaved proteins confirms the specificity of the PIPLC (B. thuringiensis) used. The failure to detect inositol 1,2-cyclic phosphate, which can be discriminated from inositol monophosphate by the TLC system used (as indicated by the position of unlabeled stained inositol 1,2-cyclic monophosphate), may be due to the limited lifetime of this reaction intermediate of bacterial PI-PLC action (Lewis et al., 1993) or to cyclic phosphodiesterase activity. Most likely, the immunodetection of hydrophilic LPL and Gcel by anti-CRD antibodies (see Figure 3) resulted from crossreactivity with an inositol monophosphate-containing epitope. The release of free inositol by nitrous acid deamination alone points to additional phosphatase action during the incubation of adipocytes or subsequent purification of the GPI-proteins.

Taken together, metabolic labeling with myo- $\left[{ }^{14} \mathrm{C}\right]$ inositol, accessibility to PI-PLC cleavage, and crossreactivity with antiCRD antibodies strongly argue for anchorage by GPI of LPL and Gcel. We therefore name the rat adipocyte cAMPbinding ectoprotein "Gcel" (glycolipid-anchored cAMPbinding ectoprotein). These findings do not exclude that a fraction of LPL is associated with the adipocyte plasma membrane via interaction with heparan sulfate proteoglycan which is also anchored in the membrane by GPI (Ishihara et al., 1987). This form of LPL can be released by heparin as has been shown by Chajek-Shaul et al. (1989) for rat heart cell cultures. However, we found that only $30-35 \%$ of the total LPL activity of rat adipocytes can be released by heparin (G. Müller, unpublished results). A total of $70-85 \%$ of the non-heparin-releasable LPL can be removed by subsequent incubation with bacterial PI-PLC, suggesting that both types of membrane anchorage of LPL coexist in rat adipocytes.

The Anti-CRD Epitope Is Masked in PI-PLC-Cleaved Solubilized Gcel. The observed membrane release of LPL and Gcel via the concerted action of PI-PLC and high salt, but not by either procedure alone, is compatible with membrane association of the two proteins via their GPI moieties and additional bipolar interactions which may involve the specific recognition of the anti-CRD epitope generated by PI-PLC action by (a) receptor protein(s) of the cell surface. This type of interaction may result in masking of the anti-CRD epitope. We tested this hypothesis for Gcel by performing immunoprecipitation studies with anti-CRD antibodies using photoaffinity-labeled or metabolically labeled and affinity-purified Gce1 from PI-PLC-treated and subsequently solubilized $(0.1 \%$ BATC) plasma membranes which have been exposed to different conditions affecting receptor-ligand interactions. Figure 5 (upper panel) shows that the amounts of solubilized total photoaffinity-labeled (lanes 1-4) or cAMP-affinitypurified metabolically labeled (lanes 5-8) Gce1 treated in a different manner prior to precipitation with PEG 6000 were 


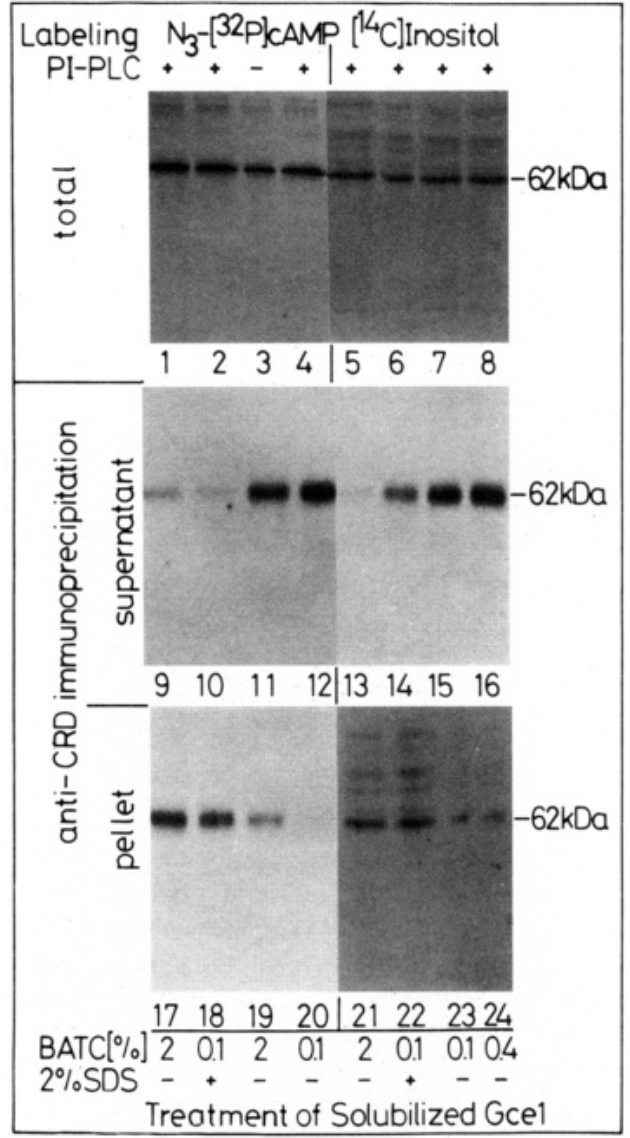

FIGURE 5: Immunoprecipitation of PI-PLC-cleaved Gce1 with antiCRD antibodies from solubilized membranes. Adipocytes were metabolically labeled with myo- $\left[{ }^{[4} \mathrm{C}\right]$ inositol (lanes 5-8, 13-16, 2124) or photoaffinity-labeled with 8- $\mathrm{N}_{3}-\left[{ }^{32} \mathrm{P}\right] \mathrm{cAMP}$ (lanes $1-4,9-12$, $17-20$ ) and then incubated in the absence (lanes $3,11,19$ ) or presence of PI-PLC (B. thuringiensis). Plasma membranes were prepared, solubilized with $0.1 \%$ BATC, and centrifuged through a cushion of sucrose. The supernatant from the metabolically labeled cells was affinity-purified on cAMP-Sepharose, and the supernatant from the photoaffinity-labeled cells was left untreated. Aliquots of the two supernatants were adjusted to a final concentration of $0.4 \%$ or $2 \%$ BATC or $2 \%$ SDS or left untreated as indicated. One half of each sample was precipitated with $8 \%$ PEG 6000 (total; upper panel). The other half of each sample was diluted to a final detergent concentration of $0.1 \%$ and then subjected to immunoprecipitation with anti-CRD antiserum preadsorbed to protein A-Sepharose. The immunoprecipitates were collected by centrifugation and washed twice with immunoprecipitation buffer containing $2 \%$ NP-40, twice with buffer containing $0.1 \%$ NP-40, and once with buffer lacking detergent (pellet; lower panel). The supernatants of the protein A-Sepharose beads were precipitated with 8\% PEG 6000 (middle panel). The PEGprecipitated or immunoprecipitated materials were suspended in sample buffer, heated, and centrifuged. The supernatants were analyzed by SDS-PAGE and fluorography.

comparable. In contrast, anti-CRD antibodies immunoprecipitated (lower panel) significant amounts of the photolabeled or metabolically labeled Gcel only if it had been treated with $2 \%$ BATC (50-70\%; lanes 17 and 21 ) or SDS (70-90\%; lanes 18 and 22) prior to incubation with the antibodies. In agreement, under these conditions only minor amounts of total labeled Gcel (2-20\%; lanes 9, 10, 13, and 14) were left in the supernatants of the corresponding anti-CRD/protein A-Sepharose complexes which are shown as a control for the efficiency of the immunoprecipitation (middle panel). Solubilized Gcel maintained at $0.1 \%$ BATC throughout the immunoprecipitation protocol did hardly react with anti-CRD antibodies (1-5\%; lanes 20 and 23). A small increase of immunoreactive Gcel (10\%; lane 24) was detected by prior incubation with $0.4 \%$ BATC. A limited portion of photoaf-
Table 1: Release of PI-PLC-Cleaved LPL and Gcel from Rat Adipocyte Plasma Membranes by Salt and Sugar Compounds ${ }^{a}$

\begin{tabular}{|c|c|c|c|c|c|}
\hline \multirow{2}{*}{$\begin{array}{l}\text { compd } \\
\text { added }\end{array}$} & \multicolumn{2}{|c|}{$\begin{array}{c}\text { \% released } \\
\text { PI-PLC-cleaved } \\
\text { GPI-protein }\end{array}$} & \multirow{2}{*}{$\begin{array}{l}\text { compd } \\
\text { added }\end{array}$} & \multicolumn{2}{|c|}{$\begin{array}{c}\text { \% released } \\
\text { PI-PLC-cleaved } \\
\text { GPI-protein }\end{array}$} \\
\hline & LPL & Gcel & & LPL & Gcel \\
\hline $\begin{array}{l}- \\
\mathrm{NaCl} \\
\text { I } \\
\text { IP } \\
\mathrm{IcP} \\
\mathrm{IP}_{3}\end{array}$ & $\begin{array}{l}22.1 \pm 4.8 \\
94.2 \pm 27.8 \\
41.7 \pm 12.3 \\
86.2 \pm 34.5 \\
92.3 \pm 17.8 \\
61.7 \pm 35.5\end{array}$ & $\begin{array}{l}36.3 \pm 6.9 \\
91.9 \pm 32.5 \\
58.4 \pm 15.7 \\
84.1 \pm 28.6 \\
90.4 \pm 15.8 \\
65.1 \pm 25.2\end{array}$ & $\begin{array}{l}\text { GlcN } \\
\text { Man } \\
\text { ManP } \\
\text { Gal } \\
\text { Glc }\end{array}$ & $\begin{array}{l}43.6 \pm 10.1 \\
28.5 \pm 9.5 \\
48.7 \pm 15.2 \\
16.8 \pm 8.5 \\
27.6 \pm 7.4\end{array}$ & $\begin{array}{l}54.8 \pm 23.1 \\
40.2 \pm 11.4 \\
58.5 \pm 15.9 \\
33.1 \pm 7.7 \\
30.3 \pm 10.9\end{array}$ \\
\hline
\end{tabular}

${ }^{a}$ Rat adipocytes were metabolically labeled with myo- $\left[{ }^{14} \mathrm{C}\right]$ inositol. Plasma membranes were isolated and treated with PI-PLC. $400-\mu \mathrm{L}$ aliquots (200 $\mu \mathrm{g}$ of protein) were supplemented with $400 \mu \mathrm{L}$ of 2 -fold membrane buffer ( $40 \mathrm{mM}$ Tris- $\mathrm{HCl}$, $\mathrm{pH} 7.4,2 \mathrm{mM}$ EDTA, $0.5 \mathrm{mM}$ DTT, $0.4 \mathrm{M}$ sucrose, $200 \mu \mathrm{M}$ PMSF) and then incubated $\left(5 \mathrm{~min}, 4^{\circ} \mathrm{C}\right)$ with $2 \mathrm{M} \mathrm{NaCl}$ or $1 \mathrm{mM}$ compound in a total volume of $1 \mathrm{~mL}$. Subsequently, the plasma membranes were centrifuged through a cushion of sucrose. One half of the supernatant was used for immunoprecipitation of LPL and the other half for affinity purification of Gcel. The proteins were analyzed by SDS-PAGE. The sliced gel bands corresponding to LDL $(60 \mathrm{kDa})$ and Gcel $(62 \mathrm{kDa})$ were counted for radioactivity. The total amount of PI-PLC-cleaved LPL and Gcel recovered from the aqueous phase after TX-114 partitioning of plasma membranes (omitting centrifugation) was set at $100 \%$ in each case. The values are the means of three independent experiments ( $\pm \mathrm{SD})$. I, myo-inositol; IP, myo-inositol 1-monophosphate; IcP, myo-inositol 1,2-cyclic monophosphate; $\mathbf{I P}_{\mathbf{3}}$, inositol 1,4,5-trisphosphate; GlcN, nonacetylated glucosamine; Man, mannose; ManP; mannose 6-phosphate; Gal, galactose; Glc, glucose.

finity-labeled uncleaved Gcel was immunoprecipitated by antiCRD antiserum after incubation with $2 \%$ BATC (10-15\%; lane 19). This is largely explained by the portion of hydrophilic Gcel generated by an endogenous adipocyte PLC activity (see above). In each case Gcel not immunoprecipitated by anti-CRD antibodies was recovered in the supernatant of the anti-CRD/protein A-Sepharose beads (compare middle and lower panels). These data suggest that the anti-CRD epitope of PI-PLC-cleaved Gcel which has been solubilized under mild conditions $(0.1 \%$ BATC) is masked by a receptor protein of the adipocyte plasma membrane. This interaction seems to be destroyed by high concentrations of detergent or denaturing conditions ( $2 \%$ SDS) and may be responsible for the retention of lipolytically cleaved GPI-proteins at the adipocyte cell surface.

Inositol Monophosphates Interfere with Membrane Association of PI-PLC-Cleaved Gcel and LPL. Tocharacterize the nature of the bipolar interactions in greater detail, $\left[{ }^{14} \mathrm{C}\right]-$ inositol-labeled plasma membranes were treated with PI-PLC and then incubated with $1 \mathrm{mM}$ of various sugar compounds (Table 1). The amount of both Gcel and LPL released into the supernatant after centrifugation was highest with inositol 1,2-cyclic monophosphate and inositol 1-monophosphate approaching the value for high-salt treatment. Inositol 1,4,5trisphosphate, mannose 6-phosphate, glucosamine, and inositol were significantly less efficient whereas mannose, glucose, and galactose were almost ineffective. About $20-40 \%$ of the total PI-PLC-cleaved hydrophilic form of LPL and Gcel was released from the plasma membranes in the absence of salt or sugar compound. This fraction may comprise molecules which have lost the structural determinants necessary for the bipolar interaction with the membrane.

Released PLC-Cleaved Gcel and LPL Reassociate with Isolated Adipocyte Plasma Membranes. The dissociation of PI-PLC-cleaved Gce1 and LPL from the membrane by inositol monophosphate suggests interaction of the terminal inositol (cyclic) monophosphate moiety of the residual GPI anchor with a component of the adipocyte plasma membrane. To 
Table 2: Reassociation of PI-PLC-Cleaved LPL and Gcel with Plasma Membranes ${ }^{a}$

\begin{tabular}{|c|c|c|c|c|c|}
\hline \multirow{2}{*}{$\begin{array}{l}\text { compd } \\
\text { added }\end{array}$} & \multicolumn{2}{|c|}{$\begin{array}{c}\text { \% reassociated } \\
\text { PI-PLC-cleaved } \\
\text { GPI-protein }\end{array}$} & \multirow{2}{*}{$\begin{array}{l}\text { compd } \\
\text { added }\end{array}$} & \multicolumn{2}{|c|}{$\begin{array}{l}\text { \% reassociated } \\
\text { PI-PLC-cleaved } \\
\text { GPI-protein }\end{array}$} \\
\hline & $\overline{\mathrm{LPL}}$ & Gcel & & LPL & Gcel \\
\hline $\begin{array}{l}\mathrm{NaCl} \\
\mathrm{I} \\
\mathrm{IP} \\
\mathrm{IcP} \\
\mathrm{IP}_{3} \\
\mathrm{GlcN}\end{array}$ & $\begin{array}{c}65.5 \pm 14.3 \\
8.8 \pm 3.9 \\
31.5 \pm 8.5 \\
12.4 \pm 5.7 \\
6.1=3.5 \\
56.9 \pm 19.3 \\
71.0 \pm 23.5\end{array}$ & $\begin{array}{c}57.8 \pm 21.5 \\
6.3 \pm 2.4 \\
35.7 \pm 12.4 \\
16.7 \pm 6.8 \\
4.3 \pm 2.5 \\
49.6 \pm 13.5 \\
61.5 \pm 18.5\end{array}$ & $\begin{array}{l}\text { Man } \\
\text { ManP } \\
\text { Gal } \\
\text { Glc } \\
\text { anti-CRD } \\
\text { preimmune } \\
\quad \text { serum }\end{array}$ & $\begin{array}{l}61.4 \pm 14.8 \\
45.6 \pm 12.4 \\
73.5 \pm 19.7 \\
71.2 \pm 28.5 \\
13.5 \pm 8.9 \\
69.5 \pm 17.7\end{array}$ & $\begin{array}{l}53.1 \pm 17.6 \\
40.8 \pm 20.4 \\
68.4 \pm 16.3 \\
62.5 \pm 17.6 \\
10.5 \pm 4.6 \\
55.6 \pm 21.3\end{array}$ \\
\hline
\end{tabular}

${ }^{a}$ Rat adipocytes were metabolically labeled with myo- $\left[{ }^{14} \mathrm{C}\right]$ inositol. Plasma membranes were isolated, treated with PI-PLC, and subjected to TX-114 partitioning. Proteins from the aqueous phase were precipitated with PEG. The pellet was suspended in membrane buffer (2000-3500 $\mathrm{dpm} / 100 \mu \mathrm{L}$ ). $100-\mu \mathrm{L}$ samples, dialyzed against membrane buffer, were incubated $\left(5 \mathrm{~min}, 4^{\circ} \mathrm{C}\right)$ with $150 \mu \mathrm{L}$ of untreated plasma membranes (1 $\mathrm{mg}$ of protein $/ \mathrm{mL}$ of membrane buffer) in the absence or presence of $2 \mathrm{M} \mathrm{NaCl}$ or $1 \mathrm{mM}$ sugar compound or $25 \mu \mathrm{L}$ of anti-CRD antiserum or preimmune serum in a total volume of $500 \mu \mathrm{L}$. Subsequently, the plasma membranes were centrifuged through a cushion of sucrose. Purification of LPL and Gcel from the membranes and quantification of the radiolabel were performed as described above. The amount of radiolabeled PI-PLC-cleaved GPI-protein added to the plasma membranes was set at $100 \%$. Each value represents the mean of three independent experiments $( \pm \mathrm{SD})$. For abbreviations see legend to Table 1 .

substantiate this interpretation, the interaction was reconstituted by incubation of isolated plasma membranes with $\left[{ }^{14} \mathrm{C}\right]$ inositol-labeled PI-PLC-cleaved GPI-proteins in the presence of $\mathrm{NaCl}$ or certain sugar compounds. In the absence of competitors $150 \mu \mathrm{g}$ of membrane protein bound up to $70 \%$ of the total hydrophilic radiolabeled LPL and Gcel added as assayed in the supernatant after centrifugation (Table 2). The amount of reassociated GPI-protein decreased to 6-12\% in the presence of $2 \mathrm{M} \mathrm{NaCl}$ or $1 \mathrm{mM}$ inositol 1,2-cyclic monophosphate and to a lower extent in the presence of $1 \mathrm{mM}$ inositol 1-monophosphate. $30-50 \%$ reductions were observed with $1 \mathrm{mM}$ inositol, inositol trisphosphate, and mannose 6-phosphate, whereas mannose, glucosamine, glucose, and galactose were completely ineffective. There was no significant difference in the ranking orders of the sugar compounds between their efficiency to displace either LPL or Gcel from native adipocyte plasma membranes (Table 1 ) and their ability to inhibit the reassociation with the membranes (Table 2), suggesting that the same type of interaction between GPIproteins and the membrane is effective in the two systems.

For quantitative evaluation of this difference the reassociation experiment was repeated using decreasing concentrations of displacing sugar compound (Figure 6). The $\mathrm{IC}_{50}$ values of the various effective sugar compounds calculated from the displacement curves for both LPL and Gcel confirmed their ranking order as defined in the previous experiment. However, the $\mathrm{IC}_{50}$ values for the inhibition of reassociation of Gcel (inositol 1,2-cyclic monophosphate: 8 $\mu \mathrm{M}$; inositol 1-monophosphate: $21 \mu \mathrm{M}$ ) were lower compared to those for LPL (inositol 1,2-cyclic monophosphate: $42 \mu \mathrm{M}$; inositol 1-monophosphate: $85 \mu \mathrm{M}$ ). Thus, the binding affinity of PI-PLC-cleaved LPL seems to be higher than that of Gce1.

The efficiency of the inositol monophosphate compounds in inhibiting the reassociation suggested that these sugars compete with the terminal inositol monophosphate moiety of PI-PLC-cleaved LPL and Gce1 for binding to a plasma membrane receptor protein. We tested this possibility by assaying the reassociation of the hydrophilic versions of the two GPI-proteins for which the terminal inositol monophos-
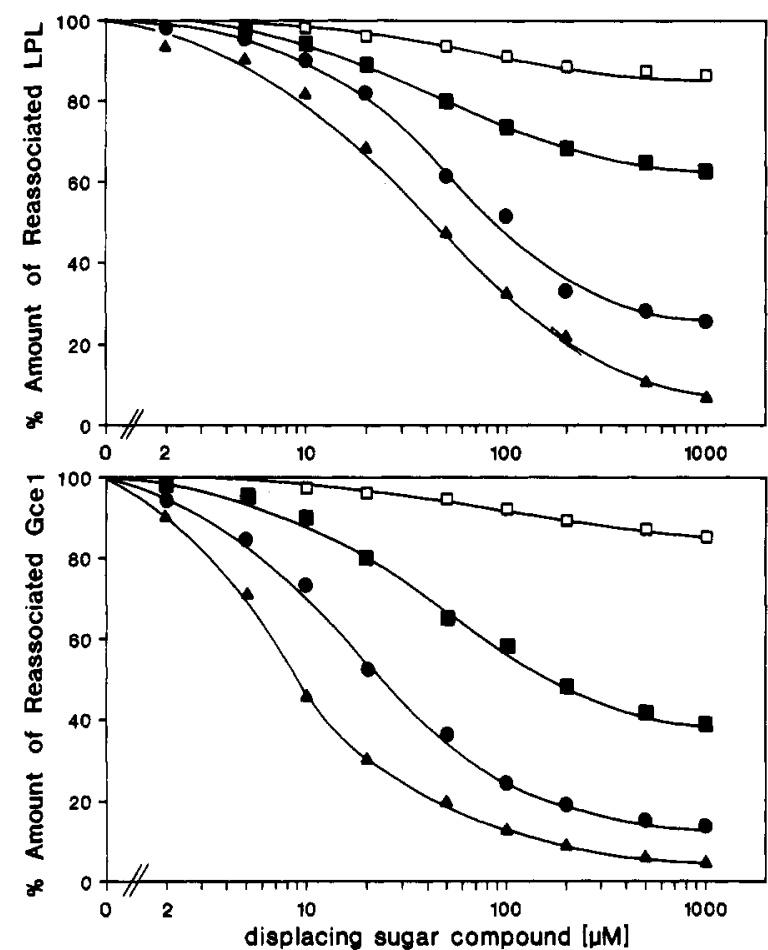

FIGURE 6: Concentration-dependent inhibition by sugar compounds of the reassociation of PI-PLC-cleaved GPI-proteins. The experiment was performed as described in the legend to Figure 7 except that for the reassociation $150 \mu \mathrm{g}$ of adipocyte plasma membranes were incubated in the presence of increasing concentrations of sugar compound. The radioactivity measured in the presence of $2 \mathrm{M} \mathrm{NaCl}$ was subtracted from each value. The specific association of radiolabeled Gcel and LPL with the membranes in the absence of sugar was set at $100 \%$. Each point represents the means of three independent experiments. $\Delta$, myo-inositol 1,2-cyclic monophosphate; $\mathbf{0}$, myoinositol 1-monophosphate; $\mathbf{\square}$, myo-inositol; $\square$, mannose.

Table 3: Reassociation of PLD-Cleaved or Deaminated LPL and Gcel with Plasma Membranes

\begin{tabular}{ccc}
\hline & \multicolumn{2}{c}{ \% reassociated } \\
& PLD-cleaved GPI-protein \\
\cline { 2 - 3 } compd added & $38.4 \pm 14.7$ & Gce 1 \\
\hline- & $4.8 \pm 2.1$ & $29.9 \pm 11.9$ \\
$\mathrm{NaCl}$ & $8.6 \pm 1.9$ & $6.7 \pm 3.0$ \\
$\mathrm{IcP}$ & $40.7 \pm 14.2$ & $11.3 \pm 4.5$ \\
$\mathrm{GlcN}$ & \multicolumn{2}{c}{ \% reassociated } \\
& \multicolumn{2}{c}{ deaminated GPI-protein } \\
\cline { 2 - 3 } & LPL & Gce 1 \\
\hline & $15.2 \pm 7.3$ & $11.2 \pm 5.8$ \\
$\mathrm{NaCl}$ & $6.4 \pm 2.8$ & $7.5 \pm 2.4$ \\
$\mathrm{IcP}$ & $17.9 \pm 8.7$ & $13.4 \pm 5.8$ \\
\hline
\end{tabular}

${ }^{a}$ The experiment was carried out as described in the legend to Table 2 with the exception that plasma membranes from which LPL and Gcel were isolated subsequently had been treated with GPI-PLD or nitrous acid. Each value represents the mean of four independent experiments ( \pm SD).

phate moiety had been removed by GPI-PLD digestion or nitrous acid deamination (Table 3 ) or had been masked by preincubation with excess of anti-CRD antibodies (Table 2). Only a limited fraction (30-40\%) of the total amount of PIPLC-cleaved hydrophilic LPL and Gce 1 was able to reassociate with the membranes. This amount was drastically diminished in the presence of $2 \mathrm{M} \mathrm{NaCl}$ or $1 \mathrm{mM}$ inositol 1,2-cyclic monophosphate but not of glucosamine. There was only a marginal reassociation of the deaminated GPI-proteins which was not inhibited by inositol 1,2-cyclic monophosphate. 


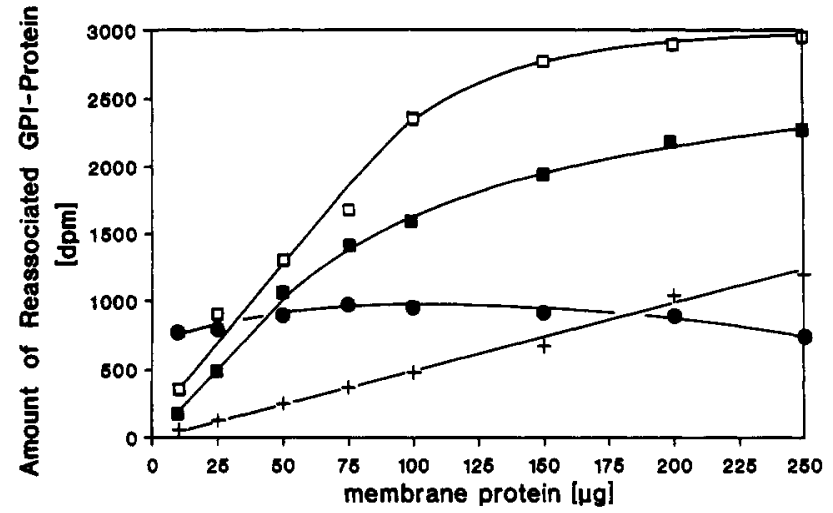

FIGURE 7: Dependence of the reassociation of PI-PLC-cleaved GPIproteins on the amount of membrane protein. Metabolically labeled proteins from PI-PLC-treated adipocyte plasma membranes (prepared as described in legend to Table 2) were incubated with various amounts of untreated or trypsin-treated $(1 \mathrm{mg} / \mathrm{mL}$ trypsin for $60 \mathrm{~min}$ at 15 ${ }^{\circ} \mathrm{C}$ followed by addition of $2 \mathrm{mg} / \mathrm{mL}$ soybean trypsin inhibitor and $200 \mu$ M PMSF) adipocyte plasma membranes or of untreated 3T3 fibroblast membranes in the absence or presence of $2 \mathrm{M} \mathrm{NaCl}$. The membranes were spun through a cushion of sucrose. The amount of radiolabeled LPL and Gcel purified from the suspended pellet fractions was determined after SDS-PAGE and densitometry of the fluorograms. For calculation of the specific association, the radioactivity measured in the presence of $2 \mathrm{M} \mathrm{NaCl}$ (unspecific association) was subtracted from the value measured in the absence of $\mathrm{NaCl}$ (total association). Each point represents the means of three to four independent experiments. $\square$, LPL associated with adipocyte plasma membranes; $\square$, Gcel associated with adipocyte plasma membranes: + , Gcel associated with fibroblast membranes; $\bullet$, Gcel associated with trypsin-treated adipocyte plasma membranes.

Furthermore, anti-CRD antibodies blocked the reassociation almost to the same degree as $2 \mathrm{M} \mathrm{NaCl}$ or $1 \mathrm{mM}$ inositol monophosphate whereas preimmune serum did not interfere. These findings strongly argue that the binding of hydrophilic GPI-proteins to rat adipocyte plasma membranes involves the terminal inositol monophosphate.

Soluble PLC-Cleaved Gce1 and LPL Compete for Binding to a Plasma Membrane Receptor Protein. The low concentrations of inositol monophosphate compounds necessary for displacement of PI-PLC-cleaved GPI-proteins from the adipocyte plasma membrane hint to the existence of a limited number of binding sites in the membrane. Consequently, we tested the dependence of the reassociation of PI-PLC-cleaved LPL and Gcel on the amount of membrane protein. Figure 7 shows that with a constant amount of LPL and Gcel the fraction of reassociated material increased with increasing amounts of membrane protein up to $75-100 \mu \mathrm{g}$ in a linear manner, leading to $55-65 \%$ association. The maximum association did not exceed $70-80 \%$, which may rely on a certain fraction of PLC-cleaved GPI-proteins having lost their ability to recognize the binding site. Membranes prepared from 3T3 fibroblasts also exhibited binding of PI-PLC-cleaved Gcel, albeit to a significantly lower degree than rat adipocyte plasma membranes. Linearity was observed with more than $250 \mu \mathrm{g}$ of fibroblast membrane protein, indicating complete saturation of all binding sites by an amount of cleaved GPI-protein which was sufficient for the saturation of $75 \mu \mathrm{g}$ of adipocyte plasma membrane protein, only. This observation demonstrates a drastically lower number of binding sites in fibroblasts compared to adipocytes.

To test whether the binding sites were constituted by membrane proteins, adipocyte plasma membranes were pretreated with trypsin followed by the addition of trypsin inhibitor, and variable amounts were assayed for reassociation of PI-PLC-cleaved Gce1 and LPL (Figure 7). A constant amount of Gcel and LPL (not shown) was recovered with
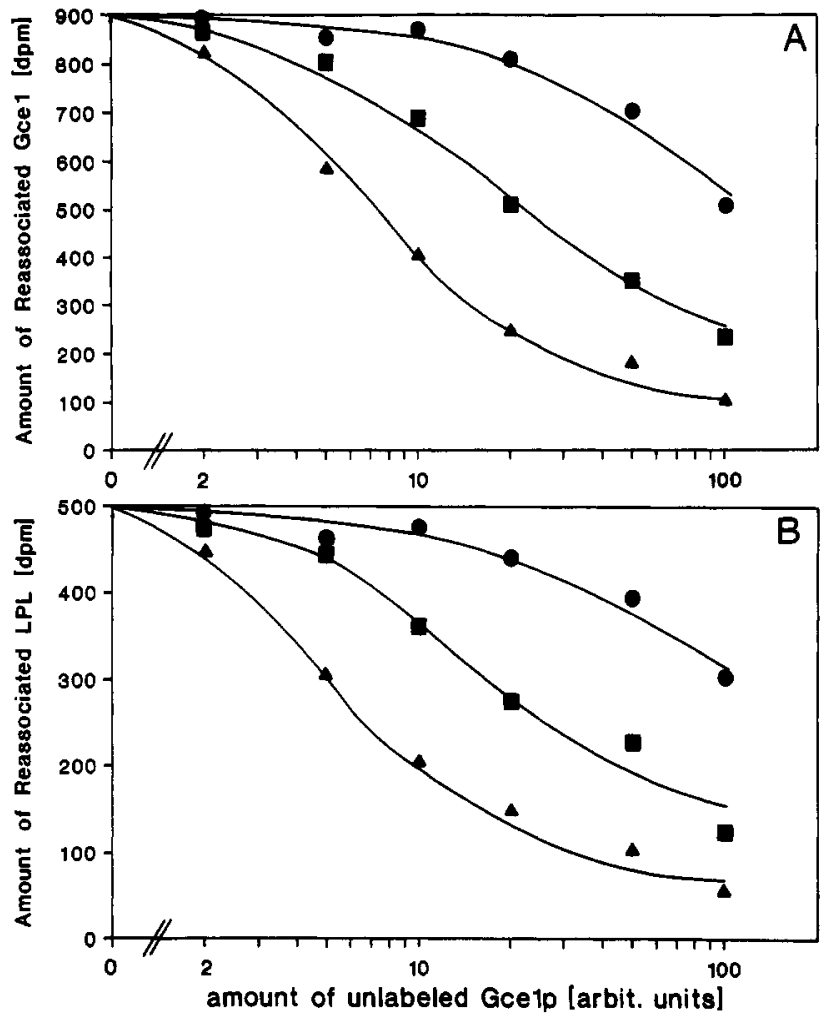

FIGURE 8: Competition of Gcel and LPL for reassociation. Rat adipocytes were metabolically labeled with myo- $\left[{ }^{14} \mathrm{C}\right]$ inositol. Plasma membranes were isolated, treated with PI-PLC, and subjected to TX-114 partitioning. Proteins from the aqueous phase $(3000-4000$ dpm per $100 \mu \mathrm{L}$ ) were incubated $\left(5 \mathrm{~min}, 4^{\circ} \mathrm{C}\right.$ ) in a total volume of $500 \mu \mathrm{L}$ with $25 \mu \mathrm{g}$ of untreated plasma membranes in the absence or presence of various amounts of PI-PLC-cleaved and affinitypurified unlabeled Gce1p from $S$. cerevisiae (the amount of Gcelp isolated from plasma membranes of $10^{8}$ yeast spheroplasts was arbitrarily set at 1 unit). Yeast Gcelp had been pretreated with PI-PLC (B. thuringiensis) (A) or GPI-PLD (rabbit serum) ( $\mathbf{(})$ or nitrous acid (๑). After incubation with plasma membranes, the mixture was centrifuged through a cushion of sucrose. Gcel (panel A) and LPL (panel B) were purified from the resuspended membranes and assayed for radioactivity as described in Figure 7. Each point represents the means of two independent experiments.

varying amounts of trypsin-treated membranes. This association was not reduced in the presence of $2 \mathrm{M} \mathrm{NaCl}$ or 1 $\mathrm{mM}$ inositol 1,2-cyclic monophosphate (data not shown). As shown above, these conditions diminished the reassociation of Gcel and LPL with even the highest amount of untreated adipocyte and fibroblast membranes to 5-10\%. Thus, trypsin treatment seems to destroy specific binding sites for PI-PLCcleaved GPI-proteins.

The inhibition of binding of PI-PLC-cleaved Gcel and LPL by various sugar compounds with the same ranking order and comparable efficiencies suggests interaction of Gcel and LPL with the same receptor protein. Further evidence for this possibility was derived from competition of the reassociation of PI-PLC-cleaved rat adipocyte Gcel and LPL by excess of purified Gcel 1 from $S$. cerevisiae. For this, PI-PLC-cleaved $\left[{ }^{14} \mathrm{C}\right]$ inositol-labeled Gcel and LPL were incubated with a limited and constant amount of untreated plasma membranes in the presence of increasing amounts of PI-PLC-cleaved affinity-purified unlabeled Gcelp isolated from plasma membranes of $S$. cerevisiae. As controls, Gcelp was prepared after cleavage with GPI-PLD or deamination with nitrous acid. Quantitative evaluation of the radiolabeled membraneassociated GPI-proteins after centrifugation (Figure 8, panel A) shows that PI-PLC-cleaved Gcelp from yeast efficiently 
competed for the reassociation of the radiolabeled PI-PLCcleaved Gcel from adipocytes. The competition was significantly less pronounced when GPI-PLD-cleaved yeast Gcelp was used and almost abolished with the deaminated protein.

Analysis of the supernatant for radiolabeled LPL revealed its displacement by the various versions of hydrophilic yeast Gcelp in a concentration-dependent manner. The ranking order and efficiencies of three versions of yeast Gcelp to displace LPL from rat adipocyte plasma membranes were the same as observed for adipocyte Gcel (panel B). The $I_{50}$ values for PI-PLC-cleaved Gcelp for displacement of adipocyte LPL and Gcel were comparable. These data provide strong evidence for interaction of the two GPI-proteins with the same adipocyte receptor protein presumably via their common terminal inositol (cyclic) monophosphate residues.

\section{DISCUSSION}

In this study we report that LPL and a cAMP-binding ectoprotein, now termed Gcel, are associated with plasma membranes of rat adipocytes via GPI structures. GPIanchored LPL and Gcel have first been described in 3T3 adipocytes (Chan et al., 1988; Müller et al., 1993) and in the yeast $S$. cerevisiae (Müller \& Bandlow, 1991). The mammalian and yeast Gcel proteins (Müller et al., 1992) share the glycoprotein nature, the GPI anchorage, and the topology, with the protein domain being located at the outer face of the plasma membrane. It is tempting to speculate about a common function of this protein in lower eucaryotes and mammalian cells as distantly related as yeast and rat adipocytes. A role in nutritional regulation has been suggested based on the observation that the GPI membrane anchors in both cell types are cleaved by an endogenous phospholipase in response to nutritional signals like glucose and insulin (Müller \& Bandlow, 1993; Müller et al., in press).

In rat adipocytes, cleavage of the GPI anchor by bacterial PI-PLC does not result per se in the release of LPL and Gcel from the cell surface. Our data strongly argue for specific recognition of the inositol (cyclic) monophosphate moiety of the PI-PLC-cleaved GPI anchor of both LPL and Gce1 by a receptor protein at the outer face of the plasma membrane. Consequently, GPI-proteins with intact GPI anchor do not interact with this receptor and, vice versa, binding of GPIproteins to the receptor requires lipolytic cleavage of their GPI anchors.

Evidence for the cleavage of GPI-proteins by specific phospholipases induced in response to hormonal and nutritional signals has been presented for a number of different cell types including cultured hepatocytes (Ishihara et al., 1987), 3T3L1 adipocytes (Chan et al., 1988; Lisanti et al., 1989; Müller et al., 1993), $\mathrm{BC}_{3} \mathrm{Hl}$ myocytes (Romero et al., 1988), and yeast (Müller \& Bandlow, 1993). Recent experiments revealed that in isolated rat adipocytes LPL and Gcel are cleaved by an endogenous PLC in response to insulin and the sulfonylurea drug, glimepiride (Müller et al., in press). Preliminary evidence suggests that the generated hydrophilic GPI-proteins a re not released from the surface of rat adipocytes or yeast spheroplasts (Müller \& Bandlow, 1993). Thus the retention mechanism for lipolytically cleaved GPI-proteins studied here with bacterial PI-PLC-cleaved LPL and Gcel may also function in vivo. Interestingly, in 3T3 adipocytes and $\mathrm{BC}_{3} \mathrm{H} 1$ myocytes PLC-cleaved GPI-proteins were recovered as soluble molecules in the culture medium (Chan et al., 1988; Romero et al., 1988; Müller et al., 1993). This lack of membrane association may be due to a limited number of binding sites and their saturation by cleaved GPI-proteins soon after stimulation of the endogenous PLC. In favor of this assumption, we observed that membranes of cultured 3T3 fibroblasts contain a significantly lower number of binding sites for PI-PLC-cleaved GPI-proteins than isolated adipocytes.

The peripheral association via bipolar interactions with a plasma membrane receptor protein may have an important regulatory role in vivo for those GPI-proteins which are destined to change their topology or location (within multicellular organisms) in response to extracellular signals. Such signals first will lead to cleavage of their GPI anchors as is the case for LPL: LPL is synthesized by adipocytes but finally will be transported to the lumenal endothelial cell surface where it interacts with circulating lipoproteins and chylomicrons. During starvation a dramatic shift of LPL activity from adipose to muscle tissue ensues [for a review see Smith and Pownall (1984)]. The first step in the extracellular LPL transport pathway is the release of LPL from the surface of adipocytes (Spooner et al., 1979) which may be initiated by circulating lipolysis products from triglyceride-rich lipoproteins (Sasaki \& Goldberg, 1992). Lipolytic cleavage of the GPI anchor of LPL in response to insulin, secreted during a previous period of food intake, will provide the pool of releasable cell surface-exposed LPL. In agreement with this hypothesis, LPL activity is low in plasma and muscle tissue of patients with severe uncontrolled diabetes which is always characterized by hypertriglyceridemia but returns to normal levels after administration of insulin or sulfonylurea (Bagdade et al., 1967). This indicates that lipolysis products per se are not sufficient to elicit dissociation of LPL from the membrane but require prior lipolytic cleavage of its GPI anchor and, vice versa, that PLC activation per se does not cause LPL release from the adipocyte surface. The lipolysis products may induce LPL release and thus ultimately regulate the flux of LPL from fat to muscle tissues by interference with the recognition of the inositol (cyclic) monophosphate residue of LPL by the adipocyte plasma membrane receptor.

A second functional role for the binding of PLC-cleaved GPI-proteins to the plasma membrane receptor may rely on mediation of the cellular uptake of GPI-proteins. In agreement with this possibility, it has been demonstrated that, after cleavage of its GPI membrane anchor by an insulin-activated PLC, heparan sulfate proteoglycan is rapidly internalized via a plasma membrane receptor which specifically recognizes the inositol monophosphate moiety of the residual GPI structure (Ishihara et al., 1987). Apart from potocytosis which involves the uptake of GPI-proteins via caveolae [for recent reviews see Anderson (1992) and Anderson et al. (1993)] and endocytosis via clathrin-coated vesicles which depends on the binding of GPI-proteins to certain transmembrane proteins as has been shown for alkaline phosphatase (Makiya et al., 1992) and urokinase-type plasminogen activator receptor (Nykjaer et al., 1992), this could represent a third mode for internalization of GPI-proteins. However, it would apply to PLC-cleaved molecules, exclusively.

Internalization of PLC-cleaved GPI-proteins may be a prerequisite for a subsequent second processing step to occur within the residual GPI anchor structure which has been demonstrated recently for Gcelp of the yeast $S$. cerevisiae (Müller et al., in preparation). Interestingly, anti-CRD antibodies drastically impair the second cleavage reaction and, as shown in this report, also interfere with the association of PLC-cleaved Gcel with the adipocyte plasma membrane. The possible relationship between binding to the receptor and the uptake/processing of GPI-proteins is under current investiga- 
tion. Taken together, binding of PLC-cleaved GPI-proteins to a cell surface receptor potentially serves two purposes: (i) storage until release into the extracellular space and (ii) storage until and mediation of internalization (and secondary processing). The structural features of the anchors or proteins for being channeled into one pathway or the other and the signals causing either release or uptake are unknown at present.

In addition, it must be taken into consideration that the retention mechanism may recognize (and mediate internalization of) not only PLC-cleaved GPI-proteins but also phosphoinositol-glycan structures which are generated in mammalian cells from free glycosylphosphatidylinositol glycolipids in response to certain growth hormones, like insulin, by activation of an endogenous PLC [for a review see Saltiel (1990)]. These molecules isolated from insulin-stimulated cells or PI-PLC-treated plasma membranes possess a terminal inositol (cyclic) monophosphate residue and can mimic certain insulin actions if incubated with intact insulin-sensitive cells (Kellerer et al., 1993; Gottschalk \& Jarett, 1988). It has been documented that the stimulation of lipogenesis by phosphoinositol-glycans in rat adipocytes is antagonized by inositol monophosphate in a concentration-dependent manner (Machicao et al., 1990). Since phosphoinositol-glycans but not inositol monophosphate are transported into cells (Alvarez et al., 1991; Stralfors \& Alemany, 1990), the inhibitory effect of exogenous inositol monophosphate appears to be exerted at the step of cellular uptake which may involve specific plasma membrane binding sites for inositol monophosphate-containing molecules as described in this study.

\section{ACKNOWLEDGMENT}

The authors are grateful to Dr. C.-S. Wang (University of Oklahoma, OK), Dr. P. Overath (Max-Planck-Institut Tübingen, FRG), and Dr. W. Gutensohn (Institut für Anthropologie und Humangenetik der Universität München, FRG) for kindly providing us with antisera against human milk LPL, anti-CRD antibodies, and partially purified GPI-PLD (rabbit serum), respectively.

\section{REFERENCES}

Anderson, R. G. W. (1993) Proc. Natl. Acad. Sci. U.S.A. 90, 10909-10913.

Anderson, R. G. W., Kamen, B. A., Rothberg, K. G., \& Lacey, S. W. (1992) Science 253, 410-411.

Alvarez, J. F., Sanchez-Arias, J. A., Guadano, A., Estevez, F., Varela, I., Feliu, J. E., \& Mato, J. M. (1991) Biochem. J. 274, 369-374

Bagdade, J. D., Porter, D., \& Bierman, E. L. (1967) N. Engl. J. Med. 276, 427-433.

Bordier, C. (1981) J. Biol. Chem. 256, 1604-1607.

Chajek-Shaul, T., Halimi, O., Ben-Naim, M., Stein, O., \& Stein, Y. (1989) Biochim. Biophys. Acta 1014, 178-183.

Chan, B. L., Lisanti, M. P., Rodriguez-Boulan, E., \& Saltiel, A. R. (1988) Science 241, 1670-1672.

Cross, G. A. M. (1990) Annu. Rev. Cell Biol. 6, 1-39.

Doering, T. L., Masterson, W. J., Hart, G. W., \& Englund, P. T. (1990) J. Biol. Chem. 265, 611-614.

Ferguson, M. A. J., \& Williams, A. F. (1988) Annu. Rev. Biochem. 57, 285-320.

Ferguson, M. A. J., Homans, S. W., Dwek, R. A., \& Rademacher,
T. W. (1988) Science 239, 753-759.

Gottschalk, W. K., \& Jarett, L. (1988) Arch. Biochem. Biophys. $261,175-185$.

Ishihara, M., Fedarko, N. S., \& Conrad, H. E. (1987) J. Biol. Chem. 262, 4708-4716.

Karnieli, E., Zarnowski, M. J., Hissin, P. J., Simpson, J. A., Salans, L. B., \& Cushman, S. W. (1981) J. Biol. Chem. 256, 4772-4777.

Kellerer, M., Machicao, F., Berti, L., Sixt, B., Mushack, J., Seffer, E., Mosthaf, L., Ullrich, A., \& Häring, H.-U. (1993) Biochem. J. 295, 699-704.

Lewis, K. A., Garigapati, V. R., Zhou, C., \& Roberts, M. F. (1993) Biochemistry 32, 8836-8841.

Lisanti, M. P., Darnell, J. C., Chan, B. L., Rodriguez-Boulan, E., \& Saltiel, A. R. (1989) Biochem. Biophys. Res. Commun. $164,824-832$.

Low, M. G. Biochim. Biophys. Acta 988, 427-454.

Machicao, F., Mushack, J., Seffer, E., Ermel, B., \& Häring, H.-U. (1990) Biochem. J. 266, 909-916.

Makiya, R., Thornell, L. E., \& Stigbrand, T. (1992) Biochem. Biophys. Res. Commun. 183, 803-808.

McConville, M. J., \& Ferguson, M. A. J. (1993) Biochem. J. 294, 305-324.

McKeel, D. W., \& Jarett, L. (1970) J. Cell Biol. 44, 417-432.

Müller, G., \& Zimmermann, R. (1987) EMBOJ. 7, 2099-2107.

Müller, G., \& Bandlow, W. (1991) Biochemistry 30, 1018110190.

Müller, G., \& Bandlow, W. (1993) J. Cell Biol. 122, 325-336.

Müller, G., \& Wied, S. (1993) Diabetes 42, 1852-1867.

Müller, G., \& Bandlow, W. (1994) Arch. Biochem. Biophys. $308,504-514$.

Müller, G., Schubert, K., Fiedler, F., \& Bandlow, W. (1992) J. Biol. Chem. 267, 25337-25346.

Müller, G., Dearey, E. A., \& Pünter, J. (1993) Biochem. J. 289, 509-521.

Müller, G., Korndörfer, A., Saar, K., Karbe-Thönges, B., Fasold, H., \& Müllner, S. (1994) Arch. Biochem. Biophys. 309, 329340.

Nykjaer, A., Petersen, C. M., Moller, B., Jensen, P. H., Moestrup, S. K., Holtet, T. L., Etzerodt, M., Thogersen, H. C., Munch, M., Andreasen, P. A., \& Gliemann, J. (1992) J. Biol. Chem. 267, 14543-14546.

Pomerantz, A. H., Rudolph, S. A., Haley, B. E., \& Greengard, P. (1975) Biochemistry 14, 3858-3862.

Popov, N., Schmitt, M., Schulzeck, S., \& Matthies, H. (1975) Acta Biol. Med. Germ. 34, 1441-1446.

Robinson, P. J., Millrain, M., Antoniou, J., Simpson, E., \& Mellor, A. L. (1989) Nature 342, 85-87.

Rodbell, M. (1964) J. Biol. Chem. 239, 375-380.

Romero, G., Luttrell, L., Rogol, A., Zeller, K., Hewlett, E., \& Larner, J. (1988) Science 240, 509-512.

Saltiel, A. R. (1990) Diabetes Care 13, 244-256.

Sasaki, A., \& Goldberg, I. J. (1992) J. Biol. Chem. 267, 1519815204.

Shenoy-Scaria, A. M., Kwong, J., Fujita, T., Olszowy, M. W., Shaw, A. S., \& Lublin, D. M. (1992) J. Immunol. 149, 35353541 .

Smith, L. C., \& Pownall, H. J. (1984) in Lipases (Borgström, B., \& Brockman, H. L., Eds.) pp 263-312, Elsevier, Amsterdam.

Spooner, P. M., Chernick, S. S., Garrison, M. M., \& Scow, R. O. (1979) J. Biol. Chem. 254, 10021-10029.

Stralfors, P., \& Alemany, S. (1990) FEBS Lett. 268, 169-172.

Su, B., Waneck, G. L., Flavell, R. A., \& Bothwell, A.L.M. (1992) J. Cell Biol. 112, 377-384.

Thomas, J. R., Dwek, R. A., \& Rademacher, T. W. (1990) Biochemistry 29, 5413-5422.

Zamze, S. E., Ferguson, M. A. J., Collins, R., Dwek, R. A., \& Rademacher, T. W. (1988) Eur. J. Biochem. 176, 527-534. 